Article

\title{
Investigation of the Dynamism of Nanosized SOA Particle Formation in Indoor Air by a Scanning Mobility Particle Sizer and Proton-Transfer-Reaction Mass Spectrometry
}

\author{
Klaudia Pytel, Renata Marcinkowska * and Bożena Zabiegała \\ Department of Analytical Chemistry, Faculty of Chemistry, Gdańsk University of Technology, 11/12 Narutowicza \\ Str. 80-233 Gdańsk, Poland; klapytel@student.pg.edu.pl (K.P.); bozena.zabiegala@pg.edu.pl (B.Z.) \\ * Correspondence: renata.marcinkowska@pg.edu.pl; Tel.: +48-58-347-21-94
}

Academic Editors: Mihkel Koel and Marek Tobiszewski

Received: 5 March 2020; Accepted: 4 May 2020; Published: 8 May 2020

\begin{abstract}
Terpenes are VOCs of particular importance, since they are emitted from a wide range of indoor sources and are considered to be precursors of Secondary Organic Aerosol (SOA) formation. It has been proven that SOA particles, especially nanosized ones, pose a threat to human health. In this research, experiments with the application of an environmental chamber and real-time measurement techniques were carried out to investigate in a complimentary way the formation of monoterpene oxidation products and nanosized SOA particles initiated by monoterpene ozonolysis. Proton-Transfer-Reaction Mass Spectrometry with a Time-Of-Flight analyzer (PTR-TOF-MS) and a Scanning Mobility Particle Sizer (SMPS) were applied to determine in real time the dynamism of the formation of the corresponding terpene ozonolysis products and submicron SOA particles. Results proved that firstly, oxidation products were formed, and then, they underwent nucleation and condensation, forming particles whose diameters grew with time. The oxidation products formed were different depending on the type of terpenes applied. The comparison of the results obtained during the experiments with gaseous standard mixtures and real samples commonly present and used in indoor air revealed that the diversified chemical composition of the emission source had implications for both the particle formation initiated by the oxidation of essential oil components and the chemical reactions occurring via the oxidation process. With the instrumentation utilized, the concentration changes at the level of a few ppbv could be monitored.
\end{abstract}

Keywords: monoterpenes; secondary organic aerosol; indoor air quality; PTR-TOF-MS; SMPS; real-time measurement techniques

\section{Introduction}

The fact that people spend only about $15 \%$ of their time outdoors [1-3] makes indoor air quality an important factor influencing human health and wellbeing. Volatile Organic Compounds (VOCs) are chemicals most commonly influencing indoor air chemistry [4]. Broadened research aimed to seek chemicals contributing to poor indoor air quality revealed that terpenes are one of the groups of VOCs strongly influencing indoor air chemistry and quality. Due to the wide range of emission sources (the main ones are: cleaning agents, air fresheners, wooden furniture, cosmetic products $[5,6]$ ), it is almost impossible to avoid or get rid of their presence in enclosed spaces. The issue concerning terpenes is associated with their high reactivity. Single or multiple double bonds in terpenes' structure are responsible for extremely fast reactions between terpenes and oxidants (ozone, hydroxyl radicals, nitrate radicals) present in indoor air [7]. Currently, scientists are sure of the first few steps of terpenes' reactions. It has been proven that firstly, terpene is attacked by ozone in the place of double bonding, 
and a primary ozonide (PO) is formed. PO is then decomposed to form the so-called "Criegee intermediate", which is highly reactive and will undergo further reactions, which are still under investigation [8-12]. Some terpenes' oxidation products may remain in a gaseous phase, while others may undergo homogeneous nucleation or condensation on preexisting particles. These processes result in the formation of ultrafine secondary organic aerosol (SOA) particles, which further evolve in size towards larger diameters [13]. An important factor influencing indoor particle growth is the presence of seed particles. Seed particles are present in indoor air mainly from the outdoor sources. A high concentration of seed particles in indoor air increases the partitioning of semi-volatile oxidation products, which leads to increased particle mass concentration indoors [14].

Investigation of the particle size distribution in indoor air is of great importance, since the particle size determines where it would deposit in the respiratory track [15]. There are several mechanisms responsible for particle deposition in a given part of the human respiratory track. Mainly, this is by diffusion, sedimentation, and impaction. Deposition mechanisms are related to particle sizes. Hence, small particles with diameters less than $0.5 \mu \mathrm{m}$ are deposited mainly through diffusion, which takes place in the alveolar interstitium, deep in the respiratory track. Particles of a diameter greater than $0.5 \mu \mathrm{m}$ are mainly deposited by sedimentation in the alveolar interstitium and tracheobronchial airway. Particles greater than $1 \mu \mathrm{m}$ are most commonly deposited by impaction in the tracheobronchial airway [16-18]. SOA particles have submicron diameters, which allow them to penetrate the human respiratory track deep into pulmonary alveoli and further into the bloodstream $[19,20]$. Numerous in vitro, in vivo, and sensory studies have demonstrated the irritating and inflammatory properties of SOA particles created by terpenes' oxidation. According to the literature data, SOA particles are responsible for: initiation of the anti-inflammatory response in human alveolar epithelium cells [21], a breath frequency decrease in mice (which is a sign of respiratory track irritation), histopathological changes in lung cells [22-25], and finally, an increase in eye blink frequency in humans (which is a sign of eye irritation) [26,27]. Due to dynamic changes in terpenes' indoor chemistry, it is still challenging to determine the chemical composition of the created SOA. Many model and experimental studies were carried out in order to determine the mechanism of terpenes' reactions with various indoor oxidants. The prediction of the reaction products and their further transformations is challenging, because terpenes' chemistry strongly depends on many factors such as humidity and the availability of substrates [28,29]. In most of the studies, reactions involving ozone were investigated because of its abundance in indoor air; however, research concerning terpenes' reactions with the hydroxyl radical is also frequently carried out [30,31]. Mathematical modelling is highly useful in predicting the products of terpene oxidation reactions. For example, the DFT method was successfully applied to predict the products of d-limonene ozonolysis. The model created predicted the formation of keto-limonene, limonoic acid, and 7-hydroxylimononaldehyde or 3-isopropenyl-6-oxo-7-hydroxy-hetanal [32], which coincided with laboratory studies. However, laboratory research revealed even more oxidation products such as limononaldehyde and keto-limononaldehyde [33]. Until now, numerous studies have been carried out to determine terpenes' oxidation mechanisms, and all of them proved that there was a wide range of different products created due to the reactions of terpenes with different oxidants and in different environmental conditions [34-38]. Terpenes' oxidation products are noticeably contributing to indoor air quality decrease by the formation of SOA, which was confirmed also by sensory analysis [39].

Taking into account the numbers of published papers dealing with terpene-derived SOA so far, it may be stated that studies on outdoor atmospheric chemistry significantly outnumber those related to indoor aerosol particles' formation (only approximately $10 \%$ of those published in the past five years addressing SOA formation concerned indoor air). However, a point to be made here is that indoor gas-phase chemistry has been thoroughly investigated for the past 20 years, which resulted in numerous papers addressing SOA formation via ozone/terpenoid reactions. As directions for future research, the indoor chemistry community indicates the application of fast-time-response instrumentation with low limits of detection in field campaigns, which would allow evaluating the results of real sample/environment studies with regard to model (chamber) studies [40]. Studies 
already reported in the literature addressing "real-world" products most of all deal with personal care or household products (e.g., air fresheners, degreasers, cleaners, perfumes etc.) [41,42].

The aim of this study was to investigate the reactions of terpenes (both generated as a standard gaseous mixture and emitted from products commonly present indoors) with ozone as an oxidant and their influence on SOA formation, growth, and distribution in time. In this work, particle number density was measured, since it brings valuable information with regard to assessment of the risk of SOA ultrafine particles' formation in indoor air on human health [43]. Mass concentration is recognized as not useful to describe the phenomenon of particle interactions with membranes or gills like sorption, translocation, or localized chemical exposure, because the same mass of smaller particles would penetrate biological barriers, when larger particles will not [43-46]. By the application of Proton-Transfer-Reaction Mass Spectrometry (PTR-MS) and a Scanning Mobility Particle Sizer (SMPS), it was possible to monitor changes in the concentration of trace or even ultra-trace organic constituents over very short periods of time with high sensitivity and ultrafine particle formation, at the same time obtaining detailed particle size distribution changes with time, both initiated by the ozonolysis of reactive VOCs commonly present in indoor air. Studies on the potential impact of terpenes'/ozone-initiated chemistry on indoor air quality involving constituents of products commonly present and used indoors are of great importance since they might contribute to solving the issue of adverse health effects that occupants report after overlong indoor residence.

\section{Results and Discussion}

The general scheme of the procedure repeated in each experiment and details regarding ozone and terpenes' concentrations are presented in Figure 1. The concentrations of reagents subjected to ozonolysis reaction were set empirically, based on the results of preliminary experiments, taking into consideration the repeatability of measurements and the clarity of the results. Each of the experiments carried out was repeated at least three times, and the spread of the results did not exceed $20 \%$. Measurement time was set with reference to a typical residence time of indoor air (the order of 1-2 h [47]), which governed the likelihood that given gaseous and particle constituent-related processes would occur.

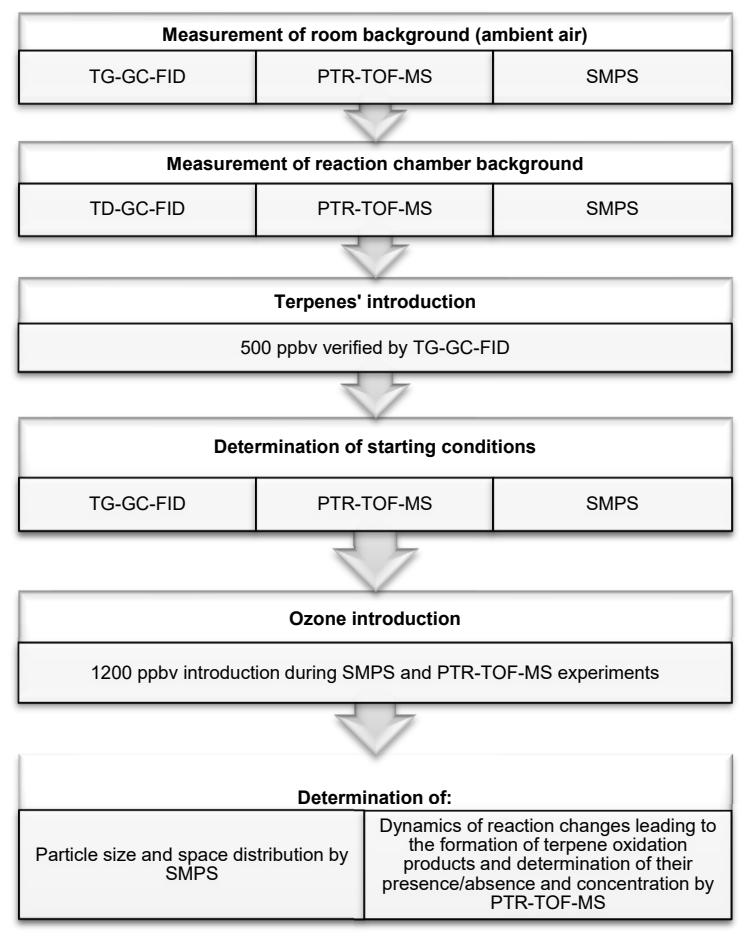

Figure 1. The main steps of the experimental part. 


\subsection{Experiments with Gaseous Standard Mixtures}

The first part of this study involved the investigation of the dynamism of the formation and chemistry of nanosized SOA particles created via the ozonolysis reaction of monoterpenes introduced into the reaction chamber as gaseous standard mixtures (see the Materials and Methods section for details).

\subsubsection{SMPS Measurements}

The results obtained by application of SMPS are presented in the form of graphs showing the change of the particle size distribution with time. Particle density was defined as the particle number density per cubic centimeter (particles $/ \mathrm{cm}^{3}$ ), while one measurement cycle was equal to $90 \mathrm{~s}$. The particle number density unit was applied, because the mass of nanoparticles was negligible (therefore almost impossible to measure) and the particle mass concentration would not provide any relevant information about the change of particle distribution in time. The particle size distribution will be denoted and abbreviated as "particle distribution" or "PSD", while particle number density or concentration will be denoted as "particle density" or "PND". Important information on SMPS experiments discussed in the following text is presented in Table 1.

Table 1. Information about the experiments carried out with the SMPS instrument.

\begin{tabular}{cccc}
\hline Experiment & $\begin{array}{c}\text { Cycle of 1st } \mathbf{O}_{\mathbf{3}} \\
\text { Introduction }\end{array}$ & $\begin{array}{c}\text { Cycle of 2nd } \mathbf{O}_{\mathbf{3}} \\
\text { Introduction }\end{array}$ & RH $^{\mathbf{1}}$ \\
\hline$\alpha$-pinene and $\mathrm{O}_{3}$ reaction & 4 th & 11 th & $59 \%$ \\
$\mathrm{~d}$-limonene and $\mathrm{O}_{3}$ reaction & 4 th & 11 th & $64 \%$ \\
$\alpha$-pinene $+\mathrm{d}$-limonene and $\mathrm{O}_{3}$ reaction & $3 \mathrm{rd}$ & 10 th & $64 \%$ \\
Scots pine wooden block emitted & $3 \mathrm{rd}$ & 12 th & $59 \%$ \\
monoterpenes and $\mathrm{O}_{3}$ reaction & $3 \mathrm{rd}$ & 7 th & $66 \%$ \\
\hline orange emitted monoterpenes and $\mathrm{O}_{3}$ reaction & & & \\
\hline
\end{tabular}

${ }^{1}$ Relative humidity.

Figure 2 shows exemplary particle measurement of reaction chamber ambient air, without terpenes' introduction (Step 1 in Figure 1).

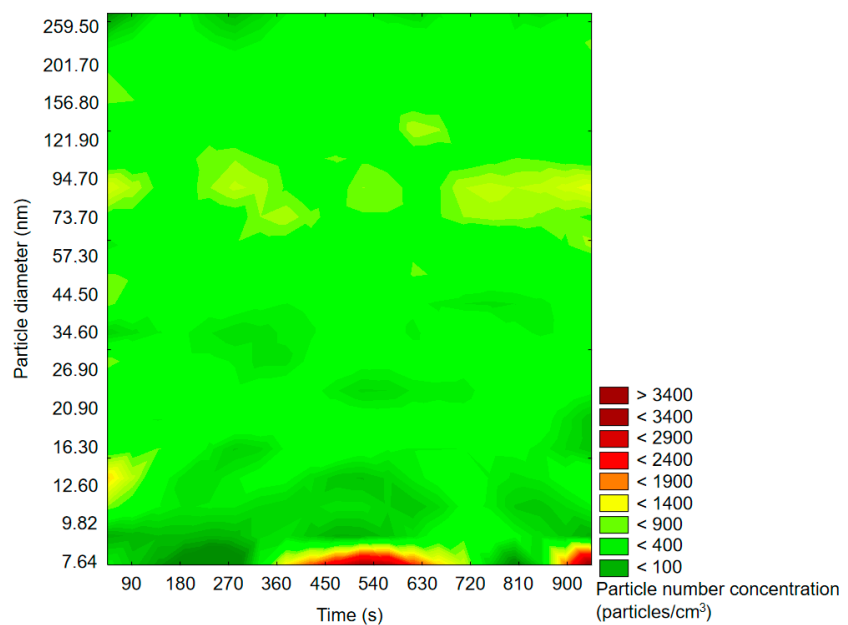

Figure 2. Exemplary results of the SMPS measurement of background particle size and space distribution.

The particle size distribution was rather uniform during the whole measurement. An increase in particle number density at the very bottom of the graph indicated that particles of a diameter smaller than $8 \mathrm{~nm}$ were possibly abundant, but the applied device settings did not allow monitoring 
particles of less than $7.64 \mathrm{~nm}$ in diameter. Background measurement showed that the magnitude of the particle number concentration before oxidation experiment was negligible taking into consideration the magnitude of PNDs after oxidant introduction; therefore, the possible interference deriving from background air may be excluded.

Figures 3 and 4 represent exemplary graphs obtained during the experiments, when either $\alpha$-pinene or d-limonene (separately) and $\mathrm{O}_{3}$ were introduced into the reaction chamber.

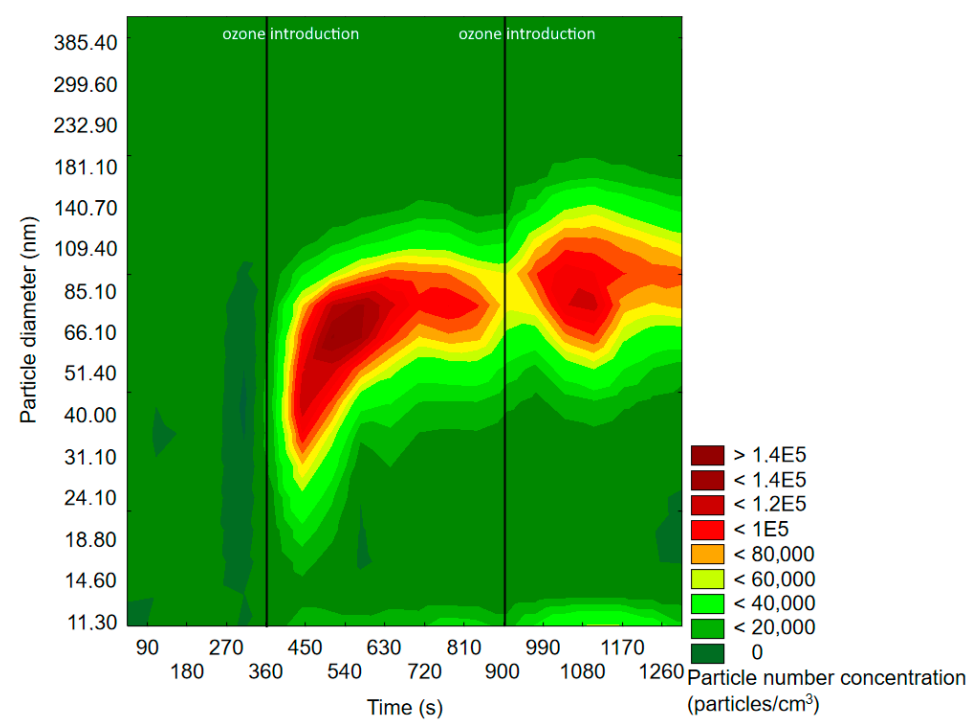

Figure 3. Exemplary results of the SMPS measurement of particle size and space distribution changes initiated by $\alpha$-pinene and $\mathrm{O}_{3}$ reaction.

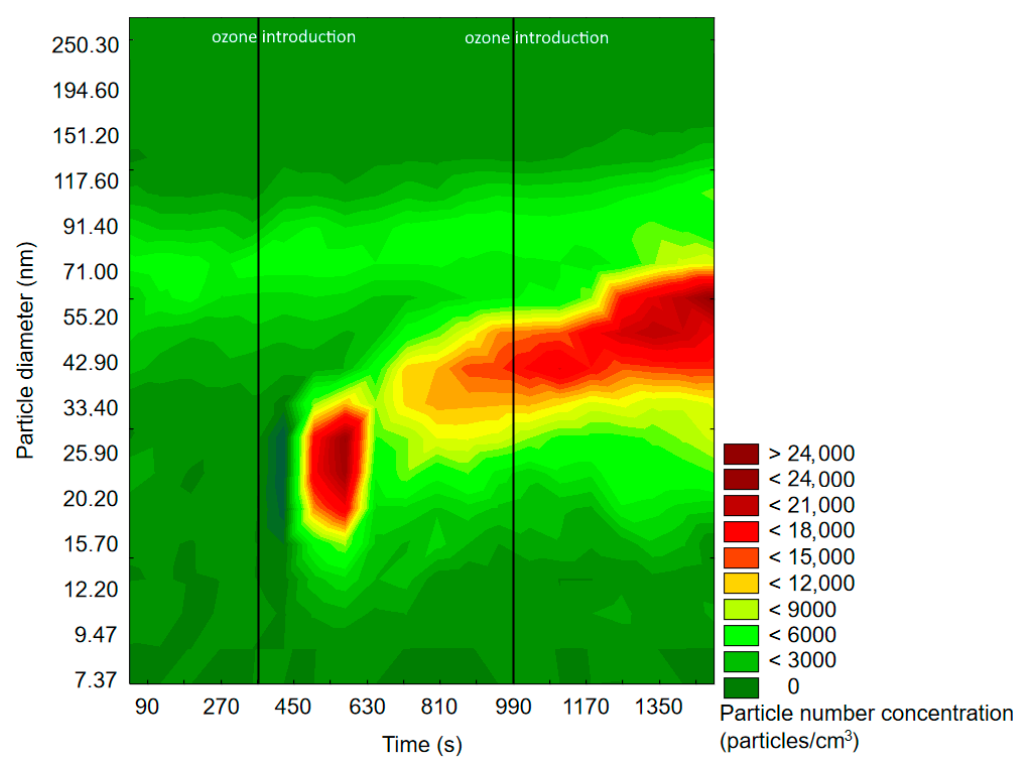

Figure 4. Exemplary results of SMPS measurement of particle size and space distribution changes initiated by d-limonene and $\mathrm{O}_{3}$ reaction.

Before ozone introduction, dominant particles were of a diameter in the range of 75-100 nm. In Figure 4 (experiment with d-limonene), there is a longitudinal area of increased PSD formed by particles of 55-117 $\mathrm{nm}$, which was present throughout the whole experiment, therefore not related to oxidation processes. In both cases, the effects of ozone introduction were comparable: first, it initiated the burst of fine particles of a diameter $<50 \mathrm{~nm}$, which was followed by rapid PND increase and a shift of the maximum concentration towards particles of diameters greater than $60 \mathrm{~nm}$. A similar trend was 
observable after subsequent ozone introduction. The first ozone introduction induced the formation of new particles, which further nucleated and grew with time into larger particles. Subsequent ozone addition resulted in both homogenous nucleation and coagulation onto already existing particles. In the case of d-limonene oxidation, after the second ozone introduction, there was a constant PND increase by the end of the measurement, which was not observed in the experiment with $\alpha$-pinene. A visible difference in the course of the formation of ultrafine SOA particles in the case of $\alpha$-pinene and d-limonene ozonolysis was possibly related to the difference in particle number concentration, which strongly influenced the aerosol condensation sink.

Figure 5 represents exemplary results of the investigation of the particle size distribution initiated via the reaction of the mixture of two terpenes ( $\alpha$-pinene and d-limonene) with ozone.

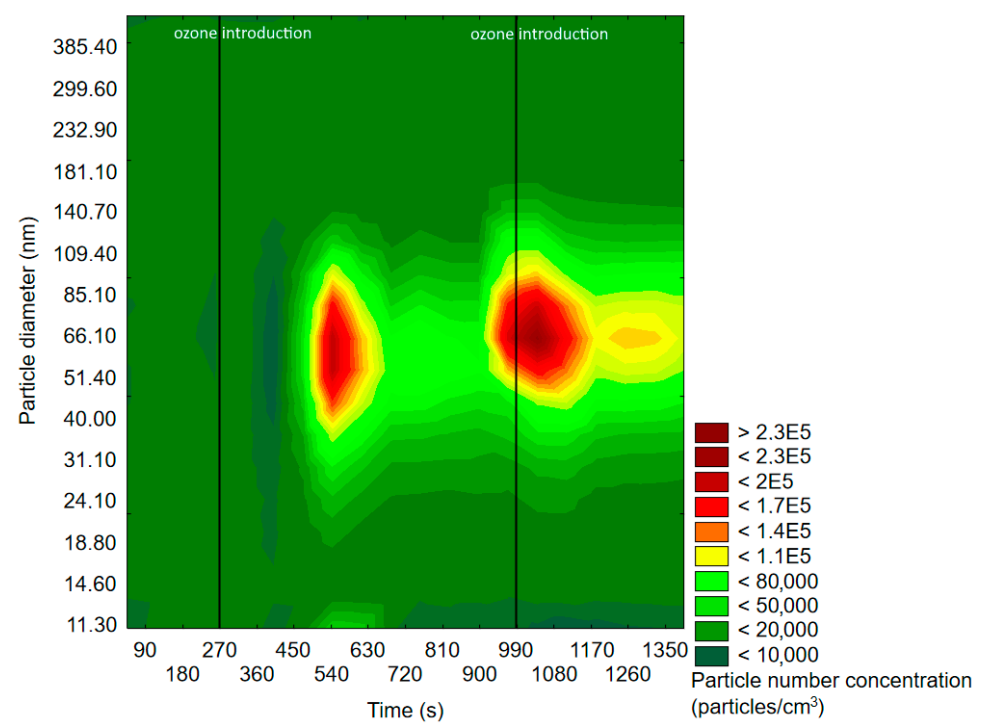

Figure 5. Exemplary results of SMPS measurement of particle size and space distribution changes initiated by $\alpha$-pinene $+\mathrm{d}$-limonene and $\mathrm{O}_{3}$ reaction.

The observed trend of particle growth was, as expected, similar to those reported in the case of experiments with single monoterpenes: the initial burst of particles of diameters $<100 \mathrm{~nm}$ was followed by a decrease in PND in a given size range and a subsequent increase in the numbers of particles of a larger size. The PND decrease at the end of the measurement accompanied with constant PSD shift towards particles of bigger diameters was most likely related to the fact that given the magnitude of PND after the second ozone addition into the reaction chamber, enhanced coagulation of newly formed particles with already existing ones took place.

All of the experiments conducted with SMPS clearly indicated the importance of the oxidant's role in the formation of ultrafine particles that could form SOA. On the basis of the obtained results, one may state that terpenes without oxidant presence did not influence the background particle number density and distribution, but each introduction of an oxidant caused visible changes. For all of the experiments, each introduction of ozone resulted in PND increase. Yet another repeatable trend was that firstly, particles of a smaller diameter were formed, and with the passing of time, the maximum particle number density shifted towards particles of a bigger diameter due to the condensation and nucleation phenomena. Particles of diameters $<20 \mathrm{~nm}$ were presumably formed in the initial steps of aerosol formation [48]; however, SMPS instrumentation settings did not allow measuring them before the nucleation event. A point to make here is that according to the literature data, the formation of the finest aerosol particles $(<5 \mathrm{~nm})$ is assigned to oxidation by $\mathrm{OH}$ radicals, whereas ozonolysis plays a greater role when the particles exceeded a diameter of $5 \mathrm{~nm}$ [49]. The observed characteristics of ultrafine particles' formation was analogous to nucleation processes occurring in atmospheric air, even 
though in this experiment, significantly higher (closer to values reported in indoor air) mixing ratios of monoterpenes and ozone were applied.

Similar phenomena of ultrafine particle formation dynamism were observed also in other reported studies on terpene-induced particle formation in indoor environments [50-52]. For instance, in the latter literature example, subsequent limonene introduction caused the same effect as subsequent ozone introduction done in the case of the experiments discussed here, namely initiating another number concentration increase of small particles, followed by size distribution shift, enhancing first the PND increase and distribution pattern. Moreover, the greatest PND increase in the reference study [52] was observed for particles of a diameter between 9 and $50 \mathrm{~nm}$, which was in accordance with the results of the experiments presented in this paper. This proved that initially, small particles were formed, and with the passing of time, the distribution shifted towards larger particles. Weschler and Shields [53] carried out experiments with a limonene source placed in offices to investigate ozone influence on sub-micron particle formation initiated by terpene ozonolysis. Those results also indicated that the ozone concentration increase caused immediate particle number density growth. There are also several other reported studies on terpene-related particle formation in specific indoor environments, such as those concerning aromatherapy spa centers [51,54] and supermarkets [55], which confirmed as well the impact of terpenes' oxidation on the formation of nano-sized particles.

\subsubsection{PTR-TOF-MS Experiments}

PTR-TOF-MS experiments were conducted to compliment the results obtained by SMPS. PTR-TOF-MS with $\mathrm{H}_{3} \mathrm{O}^{+}$soft ionization was characterized by low fragmentation of analytes. The calculation of VOCs concentration on the basis of the raw signal value (without calibration) is acceptable if the reaction rate coefficients $k$ between given $\mathrm{VOC}$ and $\mathrm{H}_{3} \mathrm{O}^{+}$ions and corresponding product branching ratios are known [56]. VOCs concentration can be calculated by the formula proposed by Lindinger and co-workers [57]:

$$
[\mathrm{VOC}]=\frac{1}{k t} \times \frac{\left[\mathrm{VOC} \cdot \mathrm{H}^{+}\right]}{\left[\mathrm{H}_{3} \mathrm{O}^{+}\right]}
$$

where: $\left[\mathrm{VOC} \cdot \mathrm{H}^{+}\right]$-ion count rates for protonated VOC ions; $\left[\mathrm{H}_{3} \mathrm{O}^{+}\right]$-ion count rate for primary ion $\mathrm{H}_{3} \mathrm{O}^{+} ; k$-reaction rate coefficient between VOC and $\mathrm{H}_{3} \mathrm{O}^{+} ; t$-residence time of primary ions in the drift tube (typically $100 \mu \mathrm{s})$

There are several papers in which the authors pointed out the importance of several factors' effects on the interference of a measurement, i.e., (i) the abundance of protonated water cluster ions $\left[\mathrm{H}_{3} \mathrm{O}\left(\mathrm{H}_{2} \mathrm{O}\right) \mathrm{n}\right]^{+}$, which depends on the PTR-MS working conditions and humidity of the sample (at "standard" operating conditions: RH 20-30\%, ambient temperature $21 \pm 1{ }^{\circ} \mathrm{C}, \mathrm{E} / \mathrm{N}$ range $120-140 \mathrm{Td}$, the ratio of the densities of $\mathrm{H}_{3} \mathrm{O}^{+} \mathrm{H}_{2} \mathrm{O}$ to $\mathrm{H}_{3} \mathrm{O}^{+}$is usually less than $3 \%$ ) [58,59]) and (ii) the possibility of the fragmentation of the compounds of interest (monoterpenes in this study) even under soft $\mathrm{H}_{3} \mathrm{O}^{+}$ionization. In order to calculate VOCs' concentration taking into account the contribution of all fragments, the following formula is used [56]:

$$
[\mathrm{VOC}]=\frac{1}{k t} \times \frac{\sqrt{(m / z)_{\mathrm{H}_{3} \mathrm{O}^{+}}}}{k t\left[\mathrm{H}_{3} \mathrm{O}^{+}\right]_{\text {measured }}} \sum_{i} \frac{\left[\mathrm{VOC}_{i} \cdot \mathrm{H}^{+}\right]_{\text {measured }}}{\sqrt{(m / z)_{\mathrm{VOC}_{i} \cdot \mathrm{H}^{+}}}}
$$

where: $\left[\mathrm{VOC}_{i} \cdot \mathrm{H}^{+}\right]$—contribution from all fragments

The PTR-TOF-MS default reaction rate constant $k$ applied to calculate the VOC concentration was equal to $2 \times 10^{-9} \mathrm{~cm}^{3}$ molecule $\mathrm{s}^{-1}$. However, for different VOCs, the $k$ values may be slightly different, e.g., the experimentally determined $k$ values for $\alpha$-pinene and limonene were equal to $2.2 \times 10^{-9} \mathrm{~cm}^{3}$ molecule $\mathrm{e}^{-1} \mathrm{~s}^{-1}$ and $2.3 \times 10^{-9} \mathrm{~cm}^{3}$ molecule $\mathrm{s}^{-1}$, correspondingly [60]. 
The application of the default reaction rate constant for the determination of VOCs concentration may cause some over- or under-estimation of the calculated concentration, but the measured $k$ values were generally within $\pm 20 \%$ of the estimated rate constant [61], which should not cause significant errors. In this experiment, the default reaction rate constant was applied. The verification of PTR-TOF-MS concentration measurements, carried out with gaseous standard mixtures of (R)-(+)-limonene and $\alpha$-pinene and the TD-GC-FID technique, revealed that the concentration measured by PTR-TOF-MS was burdened with an error in the range of $16-26 \%$ in all cases. Since the main goal of this study was to investigate the dynamism of monoterpene oxidation and the determination of the exact concentration values was not the priority, this error did not cause significant result bias.

In order to achieve the best balance between the fragmentation of the compounds of interest and the formation of water cluster ions, an E/N value equal to $103 \mathrm{Td}$ was chosen for the experiments. For instance, the monoterpene concentration was determined mainly on the basis of the $137 \mathrm{~m} / \mathrm{z}$ ion signal; therefore, it was crucial to choose an E/N value at which $137 \mathrm{~m} / \mathrm{z}$ would be the ion of the highest signal intensity. The experiments carried out with the default $\mathrm{E} / \mathrm{N}$ ratio of $122 \mathrm{Td}$ revealed the decrease in 137 $\mathrm{m} / \mathrm{z}$ ion signal intensity and the increase of the signal intensity of a main fragment ion $81 \mathrm{~m} / \mathrm{z}$.

Ions $137 \mathrm{~m} / \mathrm{z}$ and $81 \mathrm{~m} / \mathrm{z}$ were monitored in order to control monoterpenes' concentration. Only the main ions of the oxidation products are presented in the graphs, and since oxidation products' concentration changes were small and at various concentration levels, the results are presented in single graphs per each oxidation product ion (in order to make them clearer and easily visible). Other oxidation products' fragment ions are mentioned in the text.

In the following part of this subsection, the results obtained by PTR-MS measurements of the concentration of the defined compounds introduced into the reaction chamber and formed in the ozonolysis reaction that took place there are given. The origin of the coordinate system in each graph is the point where ozone was introduced into the reaction chamber and, at the same time, the starting point of concentration changes monitored by PTR-MS. It should be pointed out here that apart from the products of monoterpenes' oxidation monitored in this study, there are other (recently reported) compounds originating from monoterpenes' oxidation, precisely autoxidation, such as s $\mathrm{C}_{10} \mathrm{H}_{14} \mathrm{O}_{9}$ or $\mathrm{C}_{20} \mathrm{H}_{30} \mathrm{O}_{16}$. These low-volatility vapors are named Highly Oxygenated Molecules (HOM) and are believed to contribute in a significant way to SOA formation by nucleation on pre-existing particles. Although the formation of HOM is referred to atmospheric conditions, it should not be neglected while considering the ultrafine particle-related processes occurring indoors, especially because many important aspects of HOM formation and the properties remain unknown [62]. Nevertheless, PTR-MS in the configuration used in this study is not able to measure HOM. In spite of the limitations of the PTR-MS system to characterize HOM, in the literature, one may find reported attempts with re-designed gas inlets (which significantly reduces wall losses) and reaction chambers (30 times longer reaction time and 40 times higher pressure in comparison to the standard PTR-TOF-MS configuration) to measure HOM, which ended up with satisfactory results $[63,64]$.

Figure 6 represents exemplary results obtained during the measurement of the concentrations of the monitored compounds after $\alpha$-pinene and ozone were introduced into the reaction chamber.

The highest concentration increase was observed in the case of the $151 \mathrm{~m} / \mathrm{z}$ ion (pinonaldehyde fragment ion). The concentration increase occurred immediately after ozone introduction, but a significant rise was observable after $150 \mathrm{~s}$, simultaneously with the monoterpene concentration decrease. Parent acetone $(59 \mathrm{~m} / \mathrm{z})$ and formaldehyde $(31 \mathrm{~m} / \mathrm{z})$ ions' concentration also increased visibly. For remaining masses of pinonaldehyde fragment ions $(109 \mathrm{~m} / \mathrm{z}, 152 \mathrm{~m} / \mathrm{z})$ and the nopinone fragment ion $(139 \mathrm{~m} / \mathrm{z})$, the concentration increase occurred almost immediately after ozone introduction; however, it was not so sharply visible. The nopinone fragment ion $93 \mathrm{~m} / \mathrm{z}$ concentration changes in this experiment showed a similar (decreasing) trend as monoterpene ions $(137 \mathrm{~m} / \mathrm{z}$ and $81 \mathrm{~m} / \mathrm{z}$ ). According to another research work, the relative abundance of the mass $(93 \mathrm{~m} / \mathrm{z})$ was very low as well [30]. These patterns may be explained by different scenarios: (i) $93 \mathrm{~m} / \mathrm{z}$ was not a fragment ion of oxidation products, but a fragment ion of the monoterpene; (ii) further chemical reactions of oxidation products (nopinone 
and pinonaldehyde may undergo reactions that lead to acetone formation or reactions with $\mathrm{OH}$ radical [30]); (iii) condensation onto the formed particles (nopinone presence led to earlier nucleation in the system [65]).

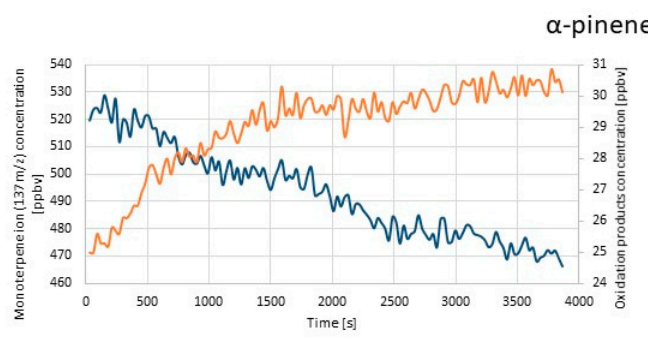

-a-pinene $137 \mathrm{~m} / 2$ —acetone $59 \mathrm{~m} / 2$

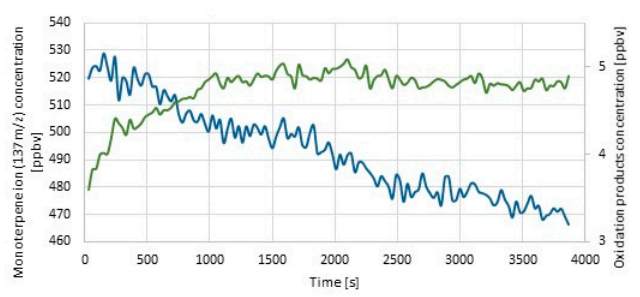

—a-pinene $137 \mathrm{~m} / 2$-nopinone $139 \mathrm{~m} / 2$ (main ion)

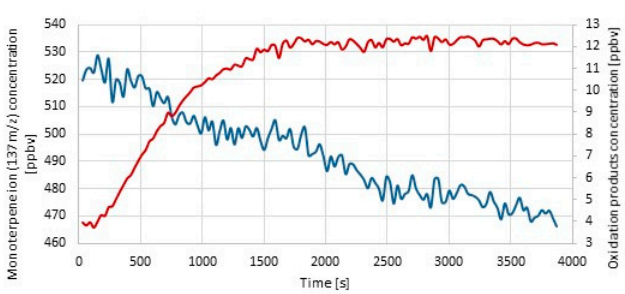

- a-pinene $137 \mathrm{~m} / 2$ - pinonaldehyde $151 \mathrm{~m} / 2$ (main ion)

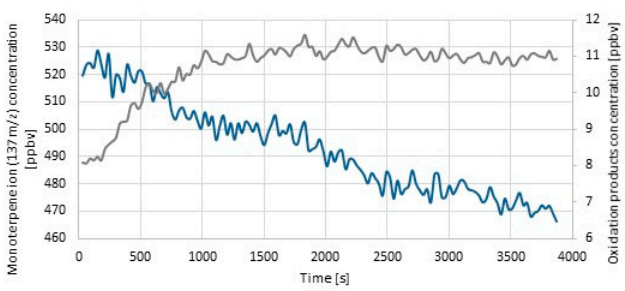

- a-pinene $137 \mathrm{~m} / 2$ — formaldehyde $31 \mathrm{~m} / 2$

Figure 6. Exemplary results of PTR-TOF-MS concentration monitoring of oxidation products formed via $\alpha$-pinene and $\mathrm{O}_{3}$ reaction.

Figure 7 represents the exemplary results of the PTR-TOF-MS measurements of the concentrations of the monitored compounds after d-limonene ozonolysis reaction.
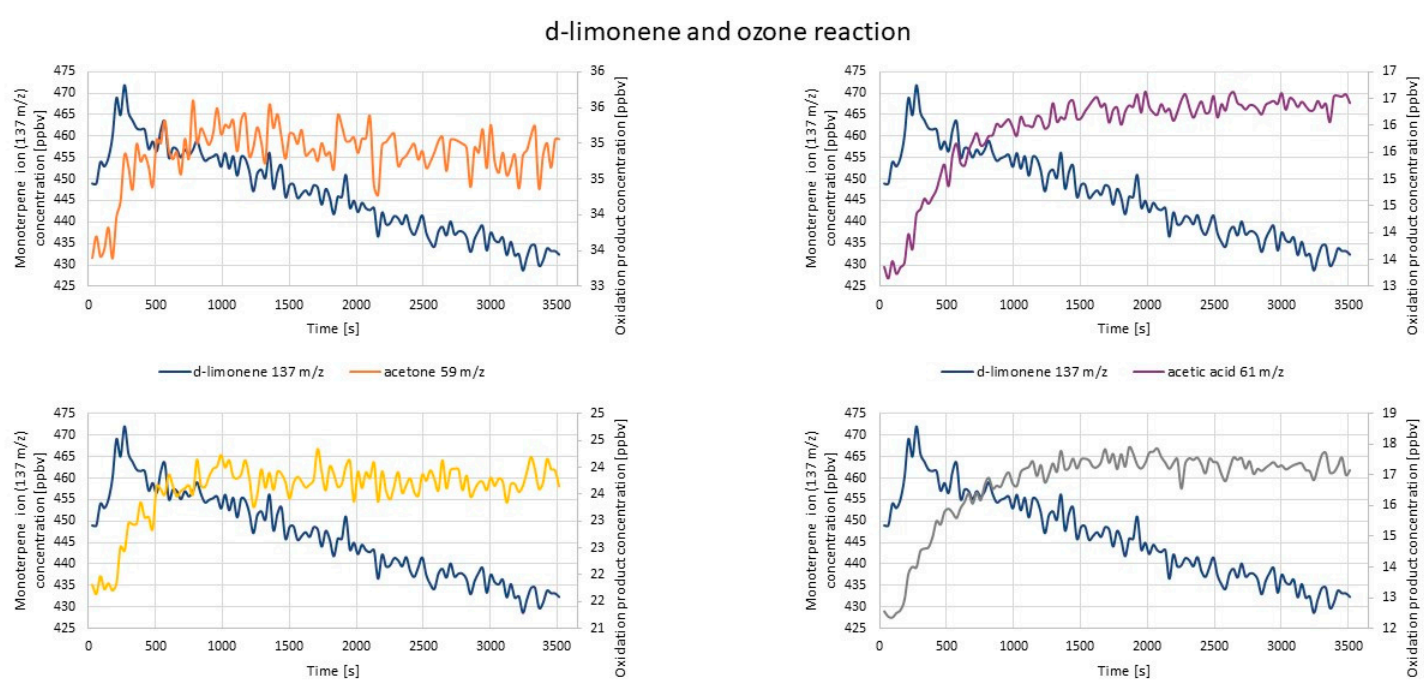

Figure 7. Exemplary results of PTR-TOF-MS concentration monitoring of oxidation products formed via d-limonene and $\mathrm{O}_{3}$ reaction.

The most visible concentration increase was in the case of formaldehyde $(31 \mathrm{~m} / \mathrm{z})$, and it started to rise immediately after ozone introduction. Evident concentration increases were also observed for acetone and acetic and formic acids $(59 \mathrm{~m} / \mathrm{z}, 61 \mathrm{~m} / \mathrm{z}$, and $47 \mathrm{~m} / \mathrm{z}$, respectively). For limonaketone $(139 \mathrm{~m} / \mathrm{z})$, a concentration increase also occurred immediately after ozone introduction. Subsequently, the concentration was rather constant, slightly decreasing at the end of the measurement. The increase 
of the concentration of $75 \mathrm{~m} / z\left(\mathrm{C}_{3} \mathrm{H}_{6} \mathrm{O}_{2}\right)$ and $155 \mathrm{~m} / z\left(\mathrm{C}_{9} \mathrm{H}_{14} \mathrm{O}_{2}\right)$ ions after ozone introduction was barely noticeable. The obtained results were in accordance with those reported in the literature [66].

Figure 8 represents exemplary results of PTR-TOF-MS concentration measurements conducted during the experiment aimed at investigation of whether the mixture of two monoterpenes would have any effect on the formation of the monitored oxidation products.

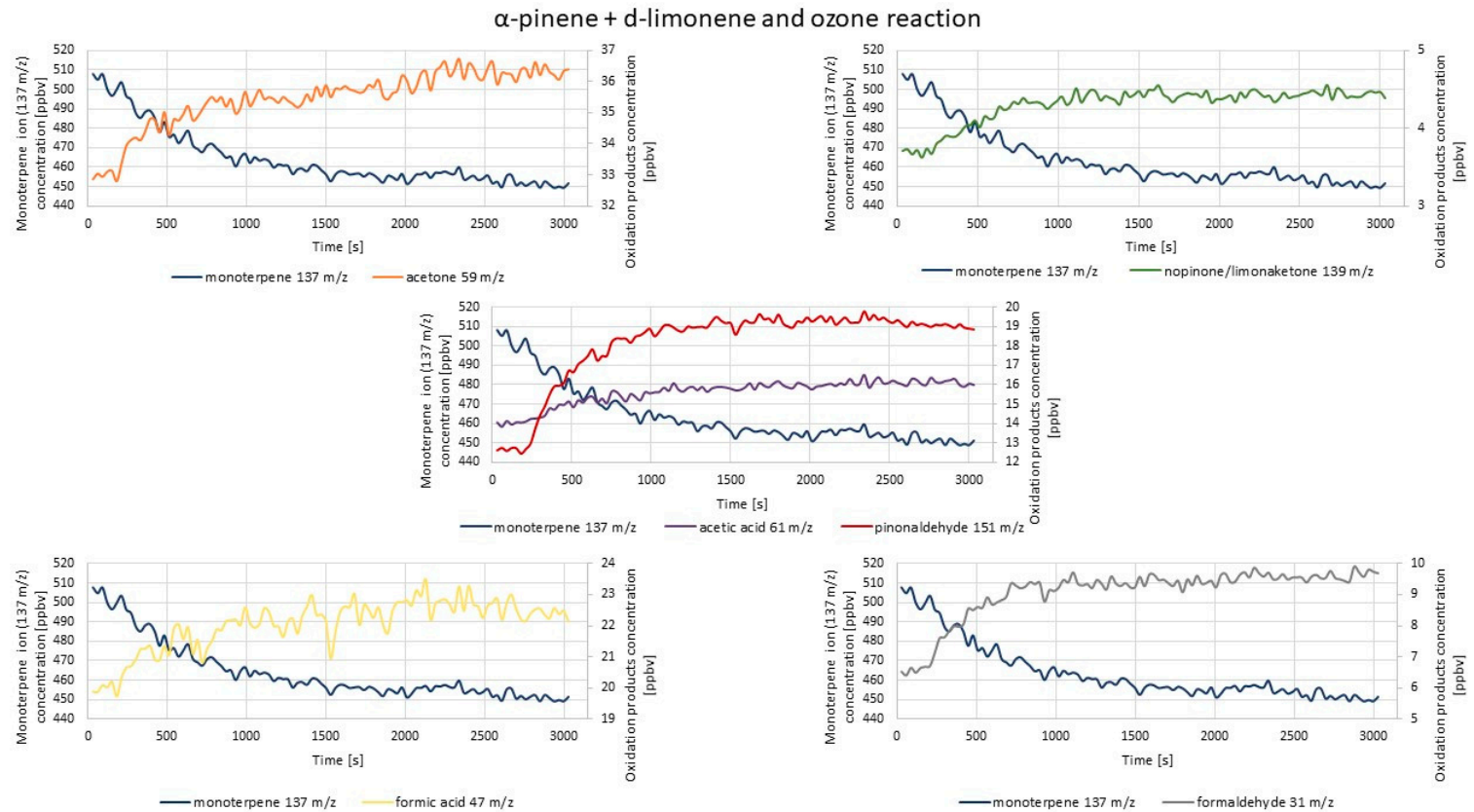

Figure 8. Exemplary results of PTR-TOF-MS concentration monitoring of oxidation products formed via $\alpha$-pinene $+\mathrm{d}$-limonene and $\mathrm{O}_{3}$ reaction.

The trends described in the previous part of this section may be observed here as well. The most visible concentration increase was for pinonaldehyde ion $151 \mathrm{~m} / \mathrm{z}$ and formaldehyde ion $31 \mathrm{~m} / \mathrm{z}(58.3 \%$ and $66.7 \%$, correspondingly). The concentration of ions $61 \mathrm{~m} / \mathrm{z}, 59 \mathrm{~m} / \mathrm{z}$, and $47 \mathrm{~m} / \mathrm{z}$ (acetic acid, acetone, and formic acid, respectively) also increased visibly during the measurement. The concentration increase of those ions lasted until the end of the measurement. One of the highest contributions observed in the case of pinonaldehyde ion $151 \mathrm{~m} / \mathrm{z}$ might not have been expected, taking into consideration the difference between the reaction rates of $\alpha$-pinene $\left(86.6 \times 10^{-18} \mathrm{~cm}^{3}\right.$ molecules $\left.^{-1} \mathrm{~s}^{-1}\right)$ and d-limonene $\left(200 \times 10^{-18} \mathrm{~cm}^{3}\right.$ molecules $\left.^{-1} \mathrm{~s}^{-1}\right)$ with ozone $[9,67]$. The higher abundance of products deriving from d-limonene ozonolysis was rather expected. This indicated that mixing two reactive components may change the anticipated (on the basis of the results obtained with these two components investigated separately) reaction products and their abundance. The primary products formed from different sources may change the course of the reactions, affecting indoor air chemistry. The nopinone fragment ion $93 \mathrm{~m} / \mathrm{z}$ concentration was decreasing since the beginning of the measurement. For other monitored ions $(109 \mathrm{~m} / \mathrm{z}, 121 \mathrm{~m} / \mathrm{z}, 139 \mathrm{~m} / \mathrm{z}, 152 \mathrm{~m} / \mathrm{z}, 155 \mathrm{~m} / \mathrm{z})$, concentration increases were hardly observable; moreover, the concentration of nopinone fragment ion $121 \mathrm{~m} / \mathrm{z}$ showed a decreasing trend throughout the measurement. The possible explanations for the decreasing nopinone concentration pattern are included above in this section. The results obtained by the introduction of the mixture of two monoterpenes were in accordance with the results obtained by separate introduction of each monoterpene into a reaction chamber.

Summarized information on these results is presented in Table 2. 
Table 2. Summary of the results of PTR-TOF-MS experiments carried out with standard gaseous mixtures.

\begin{tabular}{|c|c|c|c|c|}
\hline Experiment & Ion & $\begin{array}{l}\text { Time Lag Between } \mathrm{O}_{3} \\
\text { Introduction and First } \\
\text { Increase of the Oxidation } \\
\text { Product Concentration (s) }\end{array}$ & $\begin{array}{c}\text { Time Range while the } \\
\text { Concentration of } \\
\text { Oxidation Products } \\
\text { Was Stable (s) }\end{array}$ & $\begin{array}{l}\text { Trend at the End of the } \\
\text { Measurement } \\
\text { (increasing/decreasing/steady) }\end{array}$ \\
\hline & 59 & 60 & $1740-3150$ & increasing \\
\hline$\alpha$-pinene & 151 & 30 & $1890-3840$ & steady \\
\hline \multirow[t]{3}{*}{ ozonolysis } & 139 & 30 & $1530-2340$ & decreasing \\
\hline & 31 & 30 & $1440-2040$ & decreasing \\
\hline & 59 & 120 & 930-2190 & decreasing/steady \\
\hline d-limonene & 47 & 120 & $1290-3690$ & steady \\
\hline \multirow[t]{3}{*}{ ozonolysis } & 31 & 30 & $1290-2490$ & steady \\
\hline & 61 & 60 & - & increasing \\
\hline & 59 & 120 & - & increasing \\
\hline \multirow{5}{*}{$\begin{array}{l}\alpha \text {-pinene }+ \\
\text { d-limonene } \\
\text { ozonolysis }\end{array}$} & 47 & 120 & - & decreasing \\
\hline & 31 & 120 & 990-2190 & increasing \\
\hline & 61 & 150 & - & increasing \\
\hline & 151 & 120 & $1590-2700$ & decreasing \\
\hline & 139 & 150 & $1290-3690$ & steady \\
\hline
\end{tabular}

The greatest concentration variation was observable for $151 \mathrm{~m} / \mathrm{z}$ ion, which according to the literature data [30], was the most abundant ion of pinonaldehyde, which was in accordance with the results of this study, despite different oxidants applied during the experiments. As reported in another study, the relatively high concentrations of the $m / z 151$ ion were also produced during $\alpha$-pinene ozonolysis [68], but the authors defined this ion as deriving from verbenone, which is a possible $\alpha$-pinene oxidation product created by $\mathrm{OH}$ radical oxidation [69]. However, most commonly, the $151 \mathrm{~m} / \mathrm{z}$ ion is defined as deriving from pinonaldehyde [34,36]. Formaldehyde formation was also relatively dynamic in both experiments (monoterpenes alone and simultaneously introduced into the reaction chamber), which was in accordance with the results of reference studies $[61,66]$. Similar observation could be made in the case of acetone formation, which was not surprising, since acetone was mentioned as one of the major products created most commonly via $\alpha$-pinene reactions with $\mathrm{O}_{3}$, $\mathrm{OH}$, and $\mathrm{NO}_{x}[30,70-72]$. On the other hand, in some reported studies on monoterpenes' oxidation, acetone formation yields were rather low in the case of $d$-limonene as a substrate $[5,61,73]$. In the case of this study, despite the application of different oxidants than in reference studies, acetone formation was also greater during $\alpha$-pinene ozonolysis than during $d$-limonene ozonolysis (however, taking into consideration the measurement uncertainty, the difference may be slight). Other ions deriving from compounds formed by $\alpha$-pinene $(121 \mathrm{~m} / \mathrm{z}, 152 \mathrm{~m} / \mathrm{z}, 93 \mathrm{~m} / \mathrm{z}, 139 \mathrm{~m} / \mathrm{z}$, and $109 \mathrm{~m} / \mathrm{z})$ and d-limonene oxidation $(75 \mathrm{~m} / \mathrm{z}, 139 \mathrm{~m} / \mathrm{z}$, and $155 \mathrm{~m} / \mathrm{z})$ did not show significant concentration changes. The trend in alterations in ions $121 \mathrm{~m} / \mathrm{z}, 152 \mathrm{~m} / \mathrm{z}, 139 \mathrm{~m} / \mathrm{z}$, and $109 \mathrm{~m} / \mathrm{z}$ concentrations was similar as reported in the literature [68]: firstly, slightly increased, which was followed by a steady decrease in time. Only in the case of $93 \mathrm{~m} / \mathrm{z}$, the concentration was constantly decreasing in time, both in this experiment and others reported in the literature [68]. The comparison of the changes in the concentration of less abundant ions corresponding to d-limonene ozonolysis products with other results of chamber studies reported in the literature [66] revealed both similarities and slight differences. For instance, the $75 \mathrm{~m} / \mathrm{z}$ ion concentration measured in this study slightly increased after ozone introduction, and after $450 \mathrm{~s}$, it was constant until the end of the measurement, whereas in the reference study [66], the $75 \mathrm{~m} / \mathrm{z}$ ion concentration was increasing throughout the whole experiment. For the $155 \mathrm{~m} / \mathrm{z}$ ion, the concentration change was barely visible in this study, as well as in reference. Differences in the results may be caused by the application of different experimental conditions in the reference study [66]. Moreover, the fact that oxidation products' concentration became constant after some time in this study may be caused by the fact that there was no constant ozone supply during our experiments within the monitored time, so the substrate might have been consumed. 


\subsection{Experiments with Real Samples}

The experiments with gaseous standard mixtures were extended with the investigation involving real monoterpene emission sources: Scots pines (known to be an abundant source of $\alpha$-pinene [74]) and orange peel (as a source of limonene, which stands for $97 \%$ of the VOCs emitted from this product [75]). In this part of the study, pieces of Scots pine branch, shoots, and needles, as well as orange peel were separately placed in a micro-chamber connected to the reaction chamber, where the ozonolysis reaction was initiated (see the Materials and Methods section for details).

\subsubsection{SMPS Measurements}

Exemplary results obtained by the SMPS measurements are presented in Figures 9 and 10.

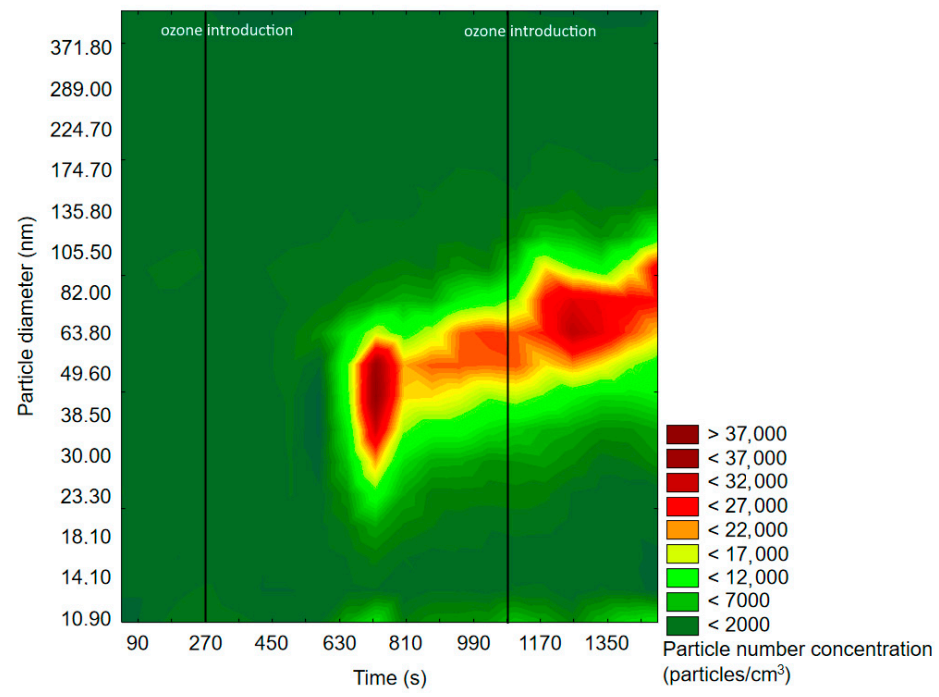

Figure 9. Exemplary results of SMPS measurement of particle size and space distribution changes initiated by Scots pine-emitted monoterpenes and $\mathrm{O}_{3}$ reaction.

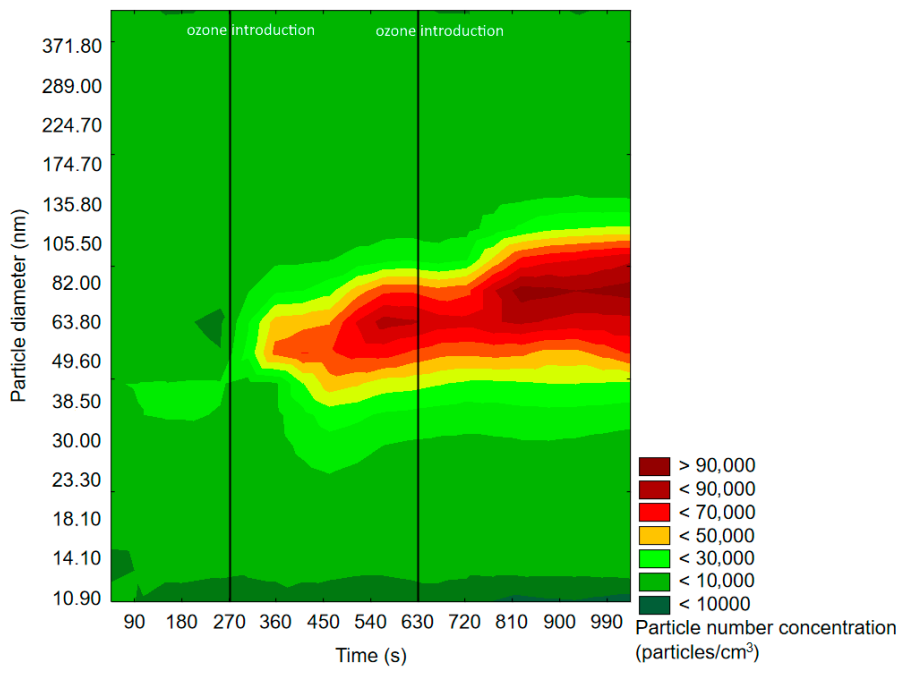

Figure 10. Exemplary results of SMPS measurement of particle size and space distribution changes initiated by orange-emitted monoterpenes and ozone reaction.

The measured maximum background PND after VOCs' emission into the reaction chamber from Scots pine and orange peel was equal to 600 particles $/ \mathrm{cm}^{3}$ and 12,200 particles $/ \mathrm{cm}^{3}$, respectively. Each ozone introduction caused an increase in PND and a shift of PSD towards bigger diameters. 
The formation of particles initiated by ozonolysis process was observed after a significantly longer period of time (more measurement cycles) during the experiment with Scots pine in comparison to the one with orange peel. This difference was most likely related to the different reactivity of the components of orange and Scots pine essential oils. The terpene composition in Scots pine essential oil is diversified, and $\alpha$-pinene is not a single dominating component there. It has been proven that branch emissions of Scots pine are rich in either 3-carene or pinenes (both $\alpha$-pinene and $\beta$-pinene); however, the percentage share of these components depends on the trees' chemodiversity. $\alpha$-pinene and 3-carene together correspond to 40-97\% of the monoterpene emission from Scots pine branch; however, a significant variability in this area has been pointed out, e.g., 10\% of investigated tree samples emitted mainly $\alpha$-pinene, and no 3-carene emission was reported, whereas in the case of $20 \%$ of the trees, 3 -carene constituted over $80 \%$ of monoterpene emission measured. The average reported emission from sampled branches was characterized by an almost equal percentage share of $\alpha$-pinene and 3-carene (ca., $40 \%$ each), $10 \%$ of $\beta$-pinene, and $10 \%$ of other compounds from monoterpene and sesquiterpene groups (e.g., limonene, camphene, terpinolene, cymene, $\beta$-caryophyllene, $\alpha$-humulene) [76-79]. In contrast, d-limonene constituted up to $97 \%$ of the orange essential oil [75], but some trace levels of other terpenes (carvone, myrcene, sabinene, etc.), aldehydes, and alcohols were also present [80]. The reaction rates of the main (ca. 90\%) Scots pine essential oil components with ozone $(\alpha$-pinene $86.6 \times 10^{-18} \mathrm{~cm}^{3}$ molecules ${ }^{-1} \mathrm{~s}^{-1} ; 3$-carene $37 \times 10^{-18} \mathrm{~cm}^{3}$ molecules $^{-1} \mathrm{~s}^{-1} ; \beta$-pinene $15 \times 10^{-18} \mathrm{~cm}^{3}$ molecules $^{-1} \mathrm{~s}^{-1}$ ) were lower than the d-limonene/ozone reaction rate, which was equal to $200 \times 10^{-18}$ $\mathrm{cm}^{3}$ molecules ${ }^{-1} \mathrm{~s}^{-1}[9,67]$; therefore, the SOA formation rate in the case of orange peel was higher. Moreover, the oxidation of the volatile fraction of orange peel seemed to produce more SOA particles than VOCs by Scots pine branch, which was consistent with the data available in the literature. It has been proven in many reported studies that limonene ozonolysis produces higher SOA levels than $\alpha$-pinene ozonolysis, which is related to different partitioning of the primary and secondary products of reaction between $\alpha$-pinene/d-limonene and ozone [81].

\subsubsection{PTR-TOF-MS Measurements}

Figures 11 and 12 represent exemplary results obtained by PTR-TOF-MS measurements during the investigation on Scots pine-/orange peel-emitted monoterpenes and ozone reaction.

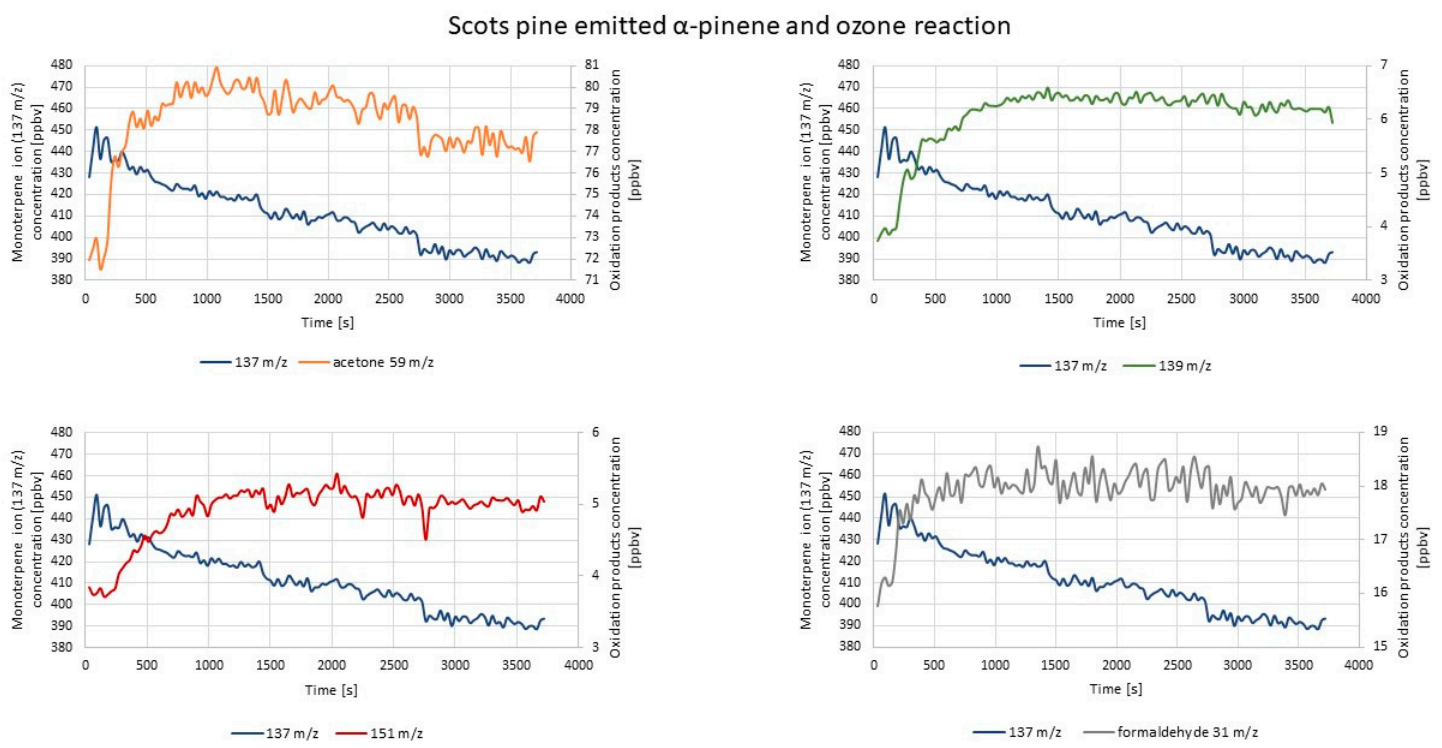

Figure 11. Exemplary results of PTR-TOF-MS concentration monitoring of oxidation products created via Scots pine-emitted monoterpenes and ozone reaction. 

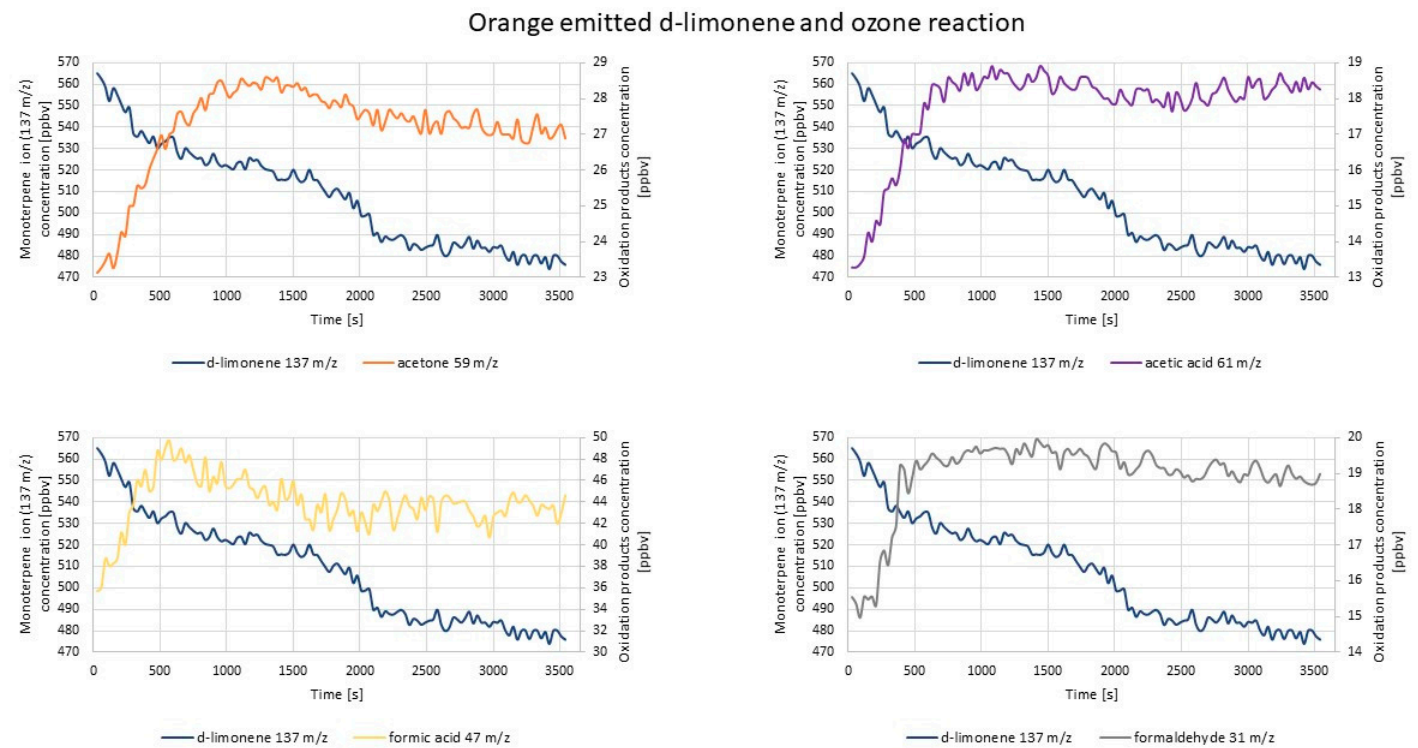

Figure 12. Exemplary results of PTR-TOF-MS concentration monitoring of oxidation products created via orange-emitted monoterpenes and ozone reaction.

Although the $\alpha$-pinene percentage share in Scots pine essential oil was rather abundant, it was not its dominant component (see the discussion in the previous section); therefore, in this case, ions $137 \mathrm{~m} / z, 139 \mathrm{~m} / \mathrm{z}$, and $151 \mathrm{~m} / \mathrm{z}$ would not be denoted as $\alpha$-pinene, nopinone, and pinonaldehyde (correspondingly) since there was the likelihood that they derived from other monoterpenes emitted from this source. Ozone introduction in this case caused the most rapid increase of acetone and formaldehyde concentration, whereas the concentration increase of the $139 \mathrm{~m} / \mathrm{z}$ ion (possibly the nopinone parent ion) was the most significant (by $50 \%$ of its initial value). For the remaining ions $121 \mathrm{~m} / \mathrm{z}, 152 \mathrm{~m} / \mathrm{z}, 151 \mathrm{~m} / \mathrm{z}$, and $109 \mathrm{~m} / \mathrm{z}$, the concentration changes were barely visible, and the $109 \mathrm{~m} / \mathrm{z}$ ion concentration decreased throughout the measurement. Such results differed from those obtained by studies involving $\alpha$-pinene gaseous standard mixture, where the $151 \mathrm{~m} / \mathrm{z}$ ion (pinonaldehyde fragment ion) concentration change was the most visible one. However, in accordance with this was the fact that the concentration changes of the ions of formaldehyde $(31 \mathrm{~m} / \mathrm{z})$ and acetone $(59 \mathrm{~m} / \mathrm{z})$ were clearly noticeable in both experiments. Differences between the results of ozonolysis of $\alpha$-pinene and Scots pine-emitted terpenes were probably related to the diversified chemical composition of Scots pine (discussed in the previous section), which had implications on both particle formation initiated by the oxidation of essential oil components and chemical reactions occurring via the oxidation process. $\alpha$-pinene was not a single dominating component in Scots pine essential oil; therefore, the abundance of oxidation products may be different in comparison to $\alpha$-pinene oxidation products.

Since d-limonene constituted over $90 \%$ of orange essential oil, ions $137 \mathrm{~m} / \mathrm{z}$ and $139 \mathrm{~m} / \mathrm{z}$ may be assigned with a high amount of certainty to d-limonene and limonaketone, correspondingly. Ozone introduction caused the most visible concentration increase of the formic acid-derived ion $(47 \mathrm{~m} / \mathrm{z})$. The limonaketone $(139 \mathrm{~m} / \mathrm{z})$ concentration increase was also sudden after ozone introduction; later, it was constant and decreased at the end of measurement. The concentration changes of ions $75 \mathrm{~m} / \mathrm{z}$ and $155 \mathrm{~m} / \mathrm{z}$ were not so significant; however, the concentrations of those ions increased within 15 min of measurement and later remained constant until the end of it. The results were similar to those obtained in the case of experiments carried out with the d-limonene standard gaseous mixture, which was expected taking into consideration the dominance of $d$-limonene in orange essential oil. There were only small differences between the concentration levels of acetone and formic acid. In the case of the application of the d-limonene standard, acetone was a product of the highest concentration, while in the case of orange peel, it was formic acid. The reason for this slight difference most likely again lied 
in the minor contribution of other than d-limonene essential oil components (see the discussion in the previous section).

The summarized information on the results obtained within PTR experiments are presented in Table 3.

Table 3. Summary of the results of PTR-TOF-MS experiments carried out with real samples.

\begin{tabular}{|c|c|c|c|c|}
\hline Experiment & Ion & $\begin{array}{l}\text { Time Lag Between } \mathrm{O}_{3} \\
\text { Introduction and the First } \\
\text { Increase of the Oxidation } \\
\text { Product Concentration (s) }\end{array}$ & $\begin{array}{l}\text { Time Range while the } \\
\text { Concentration of } \\
\text { Oxidation Products } \\
\text { Was Stable }\end{array}$ & $\begin{array}{l}\text { Trend at the End of the } \\
\text { Measurement } \\
\text { (increasing/decreasing/steady) }\end{array}$ \\
\hline \multirow{4}{*}{$\begin{array}{l}\text { Emission } \\
\text { from Scots } \\
\text { pine }\end{array}$} & 59 & 30 & - & \multirow{8}{*}{$\begin{array}{c}\text { decreasing } \\
\text { decreasing/steady } \\
\text { decreasing } \\
\text { decreasing } \\
\text { increasing } \\
\text { decreasing/steady } \\
\text { steady } \\
\text { increasing }\end{array}$} \\
\hline & 151 & 60 & $1590-2640$ & \\
\hline & 139 & 90 & $1590-3090$ & \\
\hline & 31 & 30 & $990-2790$ & \\
\hline \multirow{4}{*}{$\begin{array}{l}\text { Emission } \\
\text { from orange } \\
\text { peel }\end{array}$} & 59 & 30 & - & \\
\hline & 47 & 60 & $1830-3690$ & \\
\hline & 31 & 90 & 2430-3690 & \\
\hline & 61 & 30 & - & \\
\hline
\end{tabular}

The experiments with real samples clearly indicated the significant contribution of these natural terpenes' emission sources to SOA particles formation in indoor air, affecting in this way indoor air chemical composition. Orange peel and Scots pine branch represented different types of monoterpene emission sources indoors, meaning episodic and continuous sources. Episodic emission sources are characterized by high levels of emission in a short defined time of exposition; in this case, this would be the peeling of an orange. By this process, significant amounts of d-limonene may be introduced into the indoor air, increasing its concentration there up to tenfold [48]. Worth emphasizing is also the damaged structure of the emission source (orange peel), which affects the level of d-limonene emission indoors, unlike in the case of emission from unpeeled orange. Emission from Scots pine branch indoors may be assumed as a type of continuous emission, similar, e.g., to plug-in air fresheners (different from typical continuous sources indoors as for instance wooden furniture, but causing short-term continuous emission) and rather seasonal (e.g., Christmas trees that are present indoors in a defined period during a year). Experiments carried out with real samples proved that both episodic and continuous monoterpene emission sources significantly influenced the indoor air and therefore should be taken into account while investigating the specifics of indoor air with regard to SOA formation.

\section{Materials and Methods}

All of the experiments were carried out in a laboratory room; therefore, "ambient/background air" refers to the indoor air inside the laboratory room.

Chemical reagents applied in the study were:

- $\quad(\mathrm{R})-(+)$-limonene 97\% (Sigma Aldrich, St. Louis, Missouri, USA);

- $\quad(+)-\alpha$-pinene $98 \%$ (Sigma Aldrich, St. Louis, Missouri, USA);

- 1-butanol, EMSURE ACS (Merck, Darmstadt, Germany);

- Ozone was obtained from ozone generator GO 4-100 No 01, power supply voltage 220 V, power 50 VA.

Natural terpene emission sources applied in the study were:

- $\quad$ Orange fruit (peel);

- $\quad$ Scots pine (branch);

All experiments were conducted as follows: A crimp cap vial with a PTFE/red rubber septa filled with $0.5 \mathrm{~cm}^{3}$ of terpene (d-limonene or $\alpha$-pinene) or pieces of real samples (orange peel, Scots pine) was placed in one of the micro-chambers of $114 \mathrm{~cm}^{3}$ in volume (Micro-Chamber/Thermal Extractor Markes ${ }^{\circledR}$, 
UK, Wales, Llantrisant). The micro-chamber working temperature was $60{ }^{\circ} \mathrm{C}$, whereas the output flow rate was $40 \mathrm{~cm}^{3} \mathrm{~min}^{-1}$. A constant stream of nitrogen (99.999\%) flushed the micro-chambers for one hour, until the equilibrium state was reached, then an outlet of the micro-chamber was connected to an inlet of the reaction chamber $(63 \mathrm{~cm} \times 36 \mathrm{~cm} \times 36 \mathrm{~cm}$, made of polished stainless steel, inert to VOCs) to enrich the ambient air in the reaction chamber with terpenes or VOCs emitted from real samples. Once the required terpene concentration in the reaction chamber was reached, the inlets of SMPS and PTR-TOF-MS were connected to the reaction chamber, and the measurement was initiated. Ozone was introduced into the chamber with a gas-tight syringe through the inlet with PTFE/red rubber septa. The chamber was equipped with a mixing fan. The reaction chamber was ventilated after each experiment by opening the upper cover for $30 \mathrm{~min}$. After this time, background measurement was carried out (for $10 \mathrm{~min}$ ), and the concentrations of terpenes, formaldehyde, and acetone (main substrates and analytes controlled during experiments) were in the range of the concentrations of these compounds measured in the background air of the room.

RH was monitored with a hygrometer, and its value for the room background air was 35\%, maintained by a working air conditioning system; therefore, inside the reaction chamber, the humidity was the same during all experiments.

\subsection{SMPS Measurements}

Measurements of the size distribution of nanoparticles were done by the application of the SMPS $^{\mathrm{TM}}$ TSI GmbH 3938L50 equipped with an impactor of $0.0508 \mathrm{~cm}$ in diameter, ${ }^{85} \mathrm{Kr}$ neutralizer, Differential Mobility Analyzer (DMA) (long DMA, 44,369 cm, Model 3081A), and Condensation Particle Counter (CPC) (Model 3750). The impactor provided the cut off for the particles out of the range of measurement; the neutralizer was applied to dispose the charge of monitored particles, so they got only one, known type of charge, which reduced the electrostatic interactions between particles and the material the device was made of, whereas DMA arranged particles of different sizes according to their mobility (the specified range of voltage applied to the rod inside provided splitting and separating the particle beam of a defined size). Nanosized particles could not be detected by the usual optic detection system without the application of the condensation process, which provided an increase of the size of particles further counted by CPC. The working parameters during SMPS measurements were as follows: detector sample flow $1.0 \mathrm{dm}^{3} \mathrm{~min}^{-1}$, sheath flow $5.0 \mathrm{dm}^{3} \mathrm{~min}^{-1}$, aerosol flow 0.506 $\mathrm{dm}^{3} \mathrm{~min}^{-1}$, scan time $90 \mathrm{~s}$, voltage range $10.75-9899.38 \mathrm{~V}$, relative sample humidity 56-65\%, sample temperature $23-26{ }^{\circ} \mathrm{C}$. 1-butanol was used as the condensation fluid. The SMPS device was set in a working range to measure particles of a diameter ranging from $11.1 \mathrm{~nm}$ to $469.8 \mathrm{~nm}$. SMPS software was provided by TSI, and for the device control program, AIM 2018 TSI (TSI, Shoreview, Minnesota, USA) was applied, whereas for data analysis, Aerosol Instrument Manager TSI Version 10.3 (TSI, Shoreview, Minnesota, USA) was applied. To create graphs representing particle size distribution changes, the program Statistica 13 (StatSoft Polska Sp. z o.o., Kraków, Poland) was applied.

\subsection{PTR-TOF-MS Measurements}

Products formed via the ozonolysis reaction were detected and quantified by PTR-TOF-MS 1000 Ultra Ionicon ${ }^{\circledR}$ with $\mathrm{H} 3 \mathrm{O}+$ as primary ions. The principle of PTR-TOF-MS operation was described in detail elsewhere [82,83]. In brief, this technique applies soft $\mathrm{H}^{3} \mathrm{O}^{+}$ionization that took place only if the proton affinity of an analyte was higher than the proton affinity of water $(7.2 \mathrm{eV})$. Analytes could be determined based on the value of their mass plus the mass of a proton $\left(\mathrm{m} / \mathrm{z}^{+1}\right)$. The created ions were then separated and detected by high resolution TOF-MS. The working parameters during PTR-TOF-MS measurements were as follows: drift pressure 2.59 mbar, drift voltage $520 \mathrm{~V}, \mathrm{E} / \mathrm{N} 103 \mathrm{Td}$, drift temperature $70{ }^{\circ} \mathrm{C}$, inlet temperature $70{ }^{\circ} \mathrm{C}$, sampling velocity $1.5 \mathrm{~cm}^{3} \mathrm{~min}^{-1}$. In all experiments, the proton transfer reaction rate constant $(\mathrm{k})$ of $2 \times 10-9 \mathrm{~cm}^{3}$ molecule $\mathrm{s}^{-1} \mathrm{~s}^{-1}$ was applied. PTR software was provided by Ionicon, and for device control, the program IoniTOF Version 3.0 (Ionicon Analytic, 
Innsbruck, Austria) was applied, whereas for data analysis, the program PTR-MS Viewer Version 3.3.8 (Ionicon Analytic, Innsbruck, Austria) was used.

The masses (protonated) selected to be monitored according to literature data $[30,66,68]$ are listed below:

- $\quad \alpha$-pinene oxidation products: acetone $(59 \mathrm{~m} / \mathrm{z})$ [30]; formaldehyde $(31 \mathrm{~m} / \mathrm{z})$ [68]; nopinone (139 $\mathrm{m} / \mathrm{z}, 140 \mathrm{~m} / \mathrm{z}, 122 \mathrm{~m} / \mathrm{z}, 121 \mathrm{~m} / \mathrm{z}, 93 \mathrm{~m} / \mathrm{z}, 83 \mathrm{~m} / \mathrm{z})$; pinonaldehyde $(151 \mathrm{~m} / \mathrm{z}, 170 \mathrm{~m} / \mathrm{z}, 169 \mathrm{~m} / \mathrm{z}, 152 \mathrm{~m} / \mathrm{z}$, $123 \mathrm{~m} / \mathrm{z}, 109 \mathrm{~m} / \mathrm{z}, 108 \mathrm{~m} / \mathrm{z}, 107 \mathrm{~m} / \mathrm{z}, 99 \mathrm{~m} / \mathrm{z}, 72 \mathrm{~m} / \mathrm{z}, 71 \mathrm{~m} / \mathrm{z}, 43 \mathrm{~m} / \mathrm{z})$ [30]; pinonic acid (186 m/z); norpinonaldehyde $(155 \mathrm{~m} / \mathrm{z})$ [68]; 10-OH-pinoninc acid $(201 \mathrm{~m} / \mathrm{z})$ [68];

- d-limonene oxidation products: acetone $(59 \mathrm{~m} / \mathrm{z})$; formaldehyde $(31 \mathrm{~m} / \mathrm{z})$; formic acid $(47 \mathrm{~m} / \mathrm{z})$; $\mathrm{C}_{3} \mathrm{H}_{6} \mathrm{O}_{2}(75 \mathrm{~m} / \mathrm{z})$; limonaketone $(139 \mathrm{~m} / \mathrm{z}) ; \mathrm{C}_{9} \mathrm{H}_{14} \mathrm{O}_{2}(155 \mathrm{~m} / \mathrm{z})$; limononaldehyde $(169 \mathrm{~m} / \mathrm{z})$; acetic acid $(61 \mathrm{~m} / \mathrm{z})$; acetaldehyde $(45 \mathrm{~m} / \mathrm{z})$ [66].

The concentration of all ions listed below was determined by measuring the ion count rates of the most abundant ions (according to the literature data). It is possible that some interference from the reaction products may result in the production of other ions with these masses (even if there was no evidence of interfering ions/compounds); therefore, the measured values should be considered as upper concentration limits. Moreover, the main goal of this research was to determine the dynamism of the terpene oxidation reaction, not the precise concentration. Experiments were designed in a way to minimize terpene fragmentation, and TD-GC-FID was additionally applied to monitor terpene concentration.

All measured ion signals were corrected for PTR transmission similarly as was done in other studies [82]. To set transmission factors, the Ionicon VOC MIX 2018 standard gaseous mixture was applied. The mixture contained 7 different VOCs with the following masses $(\mathrm{m} / \mathrm{z}): 21$ (hydronium ion), 42 (acetonitrile), 59 (acetone), 79 (benzene), 93 (toluene), 107 (ethylbenzene), 113 (chlorobenzene), and 147 (dichlorobenzene). PTR software was provided by Ionicon, and for device control, the program IoniTOF Version 3.0 (Ionicon Analytic, Innsbruck, Austria) was applied, whereas for data analysis, the program PTR-MS Viewer Version 3.3.8 (Ionicon Analytic, Innsbruck, Austria) was used.

\subsection{TD-GC-FID Measurements}

The determination of terpenes' concentration in the background air and inside the chamber was carried out with the use of sorption tubes filled with Tenax TA ${ }^{\circledR} 35 / 60100 \mathrm{mg}$ (recommended for trapping VOCs from air samples [84]), a thermal desorption unit (Markes ${ }^{\circledR}$ Series 2), and a GC (Agilent Technologies 6890, MS Agilent Technologies 5973) and flame-ionization detector (GC-FID Agilent Technologies 7820A). The procedure was based on the methodology developed and applied in a different study published by the authors [85]. Before the analysis, sorbent tubes were conditioned in an inert gas atmosphere under $300{ }^{\circ} \mathrm{C}$ for $6 \mathrm{~h}$ using a thermal desorption unit (Markes ${ }^{\circledR}$ Series 2). After conditioning, the tubes' purity was verified by a blank chromatographic run (GC-FID Agilent Technologies 7820A) to confirm that the sorbent was free from impurities. Conditioned sorbent tubes were sealed using two-piece brass storage caps filled with one-piece PTFE ferrules (6 mm i.d.) and additionally closed in screw cap glass vials before analysis. To determine the concentration in the reaction chamber, $1.0 \mathrm{~L}$ of air was actively passed through the sorbent, then the tubes were sealed again and analyzed immediately. The thermal desorption parameters were as follows: $1 \mathrm{~min}$ (split ON) prepurge, $10 \mathrm{~min}$ desorption under $300^{\circ} \mathrm{C}$ (split OFF), trapping analytes under $1{ }^{\circ} \mathrm{C}$ and release onto the chromatographic column under $300{ }^{\circ} \mathrm{C}$ (split OFF), trap heating time $5 \mathrm{~min}$. The separation of the analytes was carried out on a DB1 column $(30 \mathrm{~m} \times 0.32 \mathrm{~mm} \times 5 \mu \mathrm{m}$, Agilent Technologies). The working parameters of the chromatographic system were as follows: column flow rate $2.2 \mathrm{~mL}$ $\mathrm{min}^{-1}$, temperature of TD-GC temperature program: $40^{\circ} \mathrm{C}-1 \mathrm{~min}, 10^{\circ} \mathrm{C} / \mathrm{min}-125^{\circ} \mathrm{C}, 15^{\circ} \mathrm{C} / \mathrm{min}-240$ ${ }^{\circ} \mathrm{C}-5 \mathrm{~min}$, detector temperature $250^{\circ} \mathrm{C}$. Data were evaluated by the OpenLab CDS ChemStation Workstation VL (Agilent, Santa Carla, California, USA). 


\section{Summary and Conclusions}

The results obtained by SMPS and PTR-TOF-MS were in accordance with and complementary to each other. By the application of PTR-TOF-MS, it was possible to observe the increase of monoterpene ozonolysis products' concentration (at the ppb level), the dynamism of the oxidation reaction changes, and to carry out the measurement in a real time. It was observed that firstly, the oxidation products were formed, and then, they underwent nucleation and condensation, forming particles whose diameter grew in time. At the very beginning, even a small increase in oxidation products' concentration caused an increase in PND, which was rapid and reached high values. Firstly, small particles were formed in large amounts, then the maximum particle number density decreased, and the particle size distribution shifted towards particles of a bigger diameter, which proved that the nucleation and condensation processes took place. This phenomenon was also supported by the PTR-TOF-MS results, showing that initially, oxidation products' concentration increased more rapidly, and with the passing of time, it became steady, which indicated particle formation. It was confirmed that ozone and terpene reactions led to the formation of oxidation products almost immediately after ozone introduction into the chamber containing terpenes. The formed oxidation products were different depending on the type of emission source applied. The significant concentration increases observed for formaldehyde and acetone were especially interesting, since it is generally known that those two compounds are emitted into the indoor air from various emission sources $[4,86]$ and that they alone negatively influence indoor air quality $[87,88]$. It is worth emphasizing also the results obtained within the experiments with real samples commonly present and used indoors. Peeling an orange or placing Scots pine essential oil natural emission source (e.g., Christmas tree) indoors may have a substantial impact on indoor air chemistry and indirectly contribute to adverse health effects residents report as "sick building syndrome".

Future directions in indoor air chemistry investigations concern a holistic approach of characterizing all the potential contributors to indoor air quality deterioration, i.e., human activity, reactive species emission sources, surface reservoirs, variability related to the specifics of a given indoor environment, low ventilation rates in new generation buildings, etc. The inclusion of highly oxygenated species into the compounds of interest should be also addressed. These are all aspects that may be explained most of all by the thorough investigation of processes that occur indoors, and therefore, this is worth further investigation.

Author Contributions: Conceptualization, B.Z. and R.M.; methodology, B.Z., R.M., and K.P.; experimental part, K.P.; investigation, K.P.; data curation, K.P.; writing, original draft preparation, K.P.; writing, review and editing, B.Z. and R.M.; visualization, K.P.; supervision, B.Z.; project administration, R.M.; funding acquisition, R.M. All authors have read and agreed to the published version of the manuscript.

Funding: This research received no external funding.

Acknowledgments: We would like to acknowledge TSI GmbH for loaning the SMPS instrument and NG Lab Sp. z o.o. for providing support.

Conflicts of Interest: The authors declare no conflict of interest.

\section{References}

1. Leech, J.A.; Nelson, W.C.; Burnett, R.T.; Aaron, S.; Raizenne, M.E. It's about time: A comparison of Canadian and American time-activity patterns. J. Expo. Anal. Environ. Epidemiol. 2002, 12, 427-432. [CrossRef] [PubMed]

2. Brasche, S.; Bischof, W. Daily time spent indoors in German homes - Baseline data for the assessment of indoor exposure of German occupants. Int. J. Hyg. Environ. Health 2005, 208, 247-253. [CrossRef]

3. Hussein, T.; Paasonen, P.; Kulmala, M. Activity pattern of a selected group of school occupants and their family members in Helsinki-Finland. Sci. Total Environ. 2012, 425, 289-292. [CrossRef] [PubMed]

4. Missia, D.A.; Demetriou, E.; Michael, N.; Tolis, E.I.; Bartzis, J.G. Indoor exposure from building materials: A field study. Atmos. Environ. 2010, 44, 4388-4395. [CrossRef] 
5. Wolkoff, P.; Clausen, P.; Wilkins, C.; Nielsen, G. Formation of strong airway irritants in terpene/ozone mixtures. Indoor Air 2000, 10, 82-91. [CrossRef]

6. Tsigonia, A.; Lagoudi, A.; Chandrinou, S.; Linos, A.; Evlogias, N.; Alexopoulos, E.C. Indoor air in beauty salons and occupational health exposure of cosmetologists to chemical substances. Int. J. Environ. Res. Public Health 2010, 7, 314-324. [CrossRef]

7. Wolkoff, P.; Larsen, S.T.; Hammer, M.; Kofoed-Sørensen, V.; Clausen, P.A.; Nielsen, G.D. Human reference values for acute airway effects of five common ozone-initiated terpene reaction products in indoor air. Toxicol. Lett. 2013, 216, 54-64. [CrossRef]

8. Criegee, R. Mechanism of Ozonolysis. Angew. Chem. Int. Ed. Engl. 1975, 14, 745-752. [CrossRef]

9. Atkinson, R. Gas-Phase Tropospheric Chemistry of Volatile Organic Compounds: 1. Alkanes and Alkenes. J. Phys. Chem. Ref. Data 1997, 26, 215-290. [CrossRef]

10. Berndt, T.; Böge, O.; Stratmann, F. Gas-phase ozonolysis of $\alpha$-pinene: Gaseous products and particle formation. Atmos. Environ. 2003, 37, 3933-3945. [CrossRef]

11. Atkinson, R.; Arey, J. Gas-phase tropospheric chemistry of biogenic volatile organic compounds: A review. Atmos. Environ. 2003, 37, 197-219. [CrossRef]

12. Hanson, J.R. The Ozonolysis of Terpenoids, a Pandora's Box of by-Products. J. Chem. Res. 2017, 41, $557-563$. [CrossRef]

13. Weschler, C.J. Chemistry in indoor environments: 20 years of research. Indoor Air 2011, 21, 205-218. [CrossRef]

14. Sarwar, G.; Corsi, R.; Allen, D.; Weschler, C. The significance of secondary organic aerosol formation and growth in buildings: Experimental and computational evidence. Atmos. Environ. 2003, 37, 1365-1381. [CrossRef]

15. Yeh, H.C.; Cuddihy, R.G.; Phalen, R.F.; Chang, I.Y. Comparisons of Calculated Respiratory Tract Deposition of Particles Based on the Proposed NCRP Model and the New ICRP66 Model. Aerosol Sci. Technol. 1996, 25, 134-140. [CrossRef]

16. Dockery, D.W.; Pope, A.C.; Xu, X.; Spengler, J.D.; Ware, J.H.; Fay, M.E.; Ferris, B.G.; Speizer, F.E. An Association between Air Pollution and Mortality in Six U.S. Cities. N. Engl. J. Med. 1993, 329, 1753-1759. [CrossRef] [PubMed]

17. Spengler, J.D.; Koutrakis, P.; Dockery, D.W.; Raizenne, M.; Speizer, F.E. Health Effects of Acid Aerosols on North American Children: Air Pollution Exposures. Environ. Health Perspect. 1996, 104, 492-499. [CrossRef]

18. Pope, C.A.; Dockery, D.W. Health effects of fine particulate air pollution: Lines that connect. J. Air Waste Manag. Assoc. 2006, 56, 709-742. [CrossRef]

19. Ito, K.; Harashima, H. Coupled CFD analysis of size distributions on indoor secondary organic aerosol derived from ozone/limonene reactions. Build. Environ. 2011, 46, 711-718. [CrossRef]

20. Borduas, N.; Lin, V.S. Research highlights: Laboratory studies of the formation and transformation of atmospheric organic aerosols. Environ. Sci. Process. Impacts 2016, 18, 425-428. [CrossRef]

21. Yang, G.; Sau, C.; Lai, W.; Cichon, J.; Li, W. Toxicological analysis of limonene reaction products using an in vitro exposure system. Toxicol. In Vitro 2015, 344, 1173-1178.

22. Clausen, P.A.; Wilkins, C.K.; Wolkoff, P.; Nielsen, G.D. Chemical and biological evaluation of a reaction mixture of R-(+)-limonene/ozone. Environ. Int. 2001, 26, 511-522. [CrossRef]

23. Sunil, V.R.; Laumbach, R.J.; Patel, K.J.; Turpin, B.J.; Lim, H.J.; Kipen, H.M.; Laskin, J.D.; Laskin, D.L. Pulmonary effects of inhaled limonene ozone reaction products in elderly rats. Toxicol. Appl. Pharmacol. 2007, 222, 211-220. [CrossRef] [PubMed]

24. Wolkoff, P.; Clausen, P.A.; Larsen, K.; Hammer, M.; Larsen, S.T.; Nielsen, G.D. Acute airway effects of ozone-initiated d-limonene chemistry: Importance of gaseous products. Toxicol. Lett. 2008, 181, 171-176. [CrossRef] [PubMed]

25. Wolkoff, P.; Clausen, P.A.; Larsen, S.T.; Hammer, M.; Nielsen, G.D. Airway effects of repeated exposures to ozone-initiated limonene oxidation products as model of indoor air mixtures. Toxicol. Lett. 2012, 209, 166-172. [CrossRef] [PubMed]

26. Klenø, J.; Wolkoff, P. Changes in eye blink frequency as a measure of trigeminal stimulation by exposure to limonene oxidation products, isoprene oxidation products and nitrate radicals. Int. Arch. Occup. Environ. Health 2004, 77, 235-243. [CrossRef]

27. Nøjgaard, J.K.; Christensen, K.B.; Wolkoff, P. The effect on human eye blink frequency of exposure to limonene oxidation products and methacrolein. Toxicol. Lett. 2005, 156, 241-251. [CrossRef] 
28. Wilkins, C.K.; Wolkoff, P.; Clausen, P.A.; Hammer, M.; Nielsen, G.D. Upper airway irritation of terpene/ozone oxidation products (TOPS). Dependence on reaction time, relative humidity and initial ozone concentration. Toxicol. Lett. 2003, 143, 109-114. [CrossRef]

29. Wolkoff, P.; Kjærgaard, S.K. The dichotomy of relative humidity on indoor air quality. Environ. Int. 2007, 33, 850-857. [CrossRef]

30. Wisthaler, A.; Jensen, N.R.; Winterhalter, R.; Lindinger, W.; Hjorth, J. Measurements of acetone and other gas phase product yields from the $\mathrm{OH}$-initiated oxidation of terpenes by proton-transfer-reaction mass spectrometry (PTR-MS). Atmos. Environ. 2001, 35, 6181-6191. [CrossRef]

31. Peeters, J.; Müller, J.F.; Stavrakou, T.; Nguyen, V.S. Hydroxyl radical recycling in isoprene oxidation driven by hydrogen bonding and hydrogen tunneling: The upgraded LIM1 mechanism. J. Phys. Chem. A 2014, 118, 8625-8643. [CrossRef]

32. Sun, T.; Wang, Y.; Zhang, C.; Sun, X.; Wang, W. The chemical mechanism of the limonene ozonolysis reaction in the SOA formation: A quantum chemistry and direct dynamic study. Atmos. Environ. 2011, 45, 1725-1731. [CrossRef]

33. Leungsakul, S.; Jaoui, M.; Kamens, R.M. Kinetic mechanism for predicting secondary organic aerosol formation from the reaction of d-limonene with ozone. Environ. Sci. Technol. 2005, 39, 9583-9594. [CrossRef]

34. Glasius, M.; Duane, M.; Larsen, B.R. Determination of polar terpene oxidation products in aerosols by liquid chromatography-ion trap mass spectrometry. J. Chromatogr. 1999, 833, 121-135. [CrossRef]

35. Koch, S.; Winterhalter, R.; Uherek, E.; Kolloff, A.; Neeb, P.; Moortgat, G.K. Formation of new particles in the gas-phase ozonolysis of monoterpenes. Atmos. Environ. 2000, 34, 4031-4042. [CrossRef]

36. Jenkin, M.E. Modelling the formation and composition of secondary organic aerosol from $\alpha$ - and $\beta$-pinene ozonolysis using MCM v3. Atmos. Chem. Phys. Discuss. 2004, 4, 2905-2948. [CrossRef]

37. Leungsakul, S.; Jeffries, H.E.; Kamens, R.M. A kinetic mechanism for predicting secondary aerosol formation from the reactions of d-limonene in the presence of oxides of nitrogen and natural sunlight. Atmos. Environ. 2005, 39, 7063-7082. [CrossRef]

38. Ng, N.L.; Kwan, A.J.; Surratt, J.D.; Chan, A.W.H.; Chhabra, P.S.; Sorooshian, A.; Pye, H.O.T.; Crounse, J.D.; Wennberg, P.O.; Flagan, R.C.; et al. Secondary organic aerosol (SOA) formation from reaction of isoprene with nitrate radicals (NO3). Atmos. Chem. Phys. 2008, 8, 4117-4140. [CrossRef]

39. Tamás, G.; Weschler, C.J.; Toftum, J.; Fanger, P.O. Influence of ozone-limonene reactions on perceived air quality. Indoor Air 2006, 16, 168-178. [CrossRef]

40. Weschler, C.J.; Carslaw, N. Indoor Chemistry. Environ. Sci. Technol. 2018, 52, 2419-2428. [CrossRef]

41. Singer, B.C.; Coleman, B.K.; Destaillats, H.; Hodgson, A.T.; Lunden, M.; Weschler, C.; Nazaroff, W.W. Indoor secondary pollutants from cleaning product and air freshener use in the presence of ozone. Atmos. Environ. 2006, 40, 6696-6710. [CrossRef]

42. Carslaw, N. A mechanistic study of limonene oxidation products and pathways following cleaning activities. Atmos. Environ. 2013, 80, 507-513. [CrossRef]

43. Kennedy, A.J.; Diamond, S.; Stanley, J.K.; Coleman, J.; Steevens, J.A.; Chappell, M.A.; Laird, J.; Bednar, A. Nanomaterials Ecotoxicology: A Case Study with Nanosilver. In Nanotechnology Environmental Health and Safety; Elsevier: Amsterdam, The Netherlands, 2014; pp. 117-151.

44. Brown, D.M.; Wilson, M.R.; Macnee, W.; Stone, V.; Donaldson, K. Size-Dependent Proinflammatory Effects of Ultrafine Polystyrene Particles: A Role for Surface Area and Oxidative Stress in the Enhanced Activity of Ultrafines Size-Dependent Proinflammatory Effects of Ultrafine Polysty-rene Particles: A Role for Surface Area and Oxidative Stress in the Enhanced Activity of Ultrafines. Toxicol. Appl. Pharmacol. 2001, 175, 191-199.

45. Wittmaack, K. In Search of the Most Relevant Parameter for Quantifying Lung Inflammatory Response to Nanoparticle Exposure: Particle Number, Surface Area, or What? Environ. Health Perspect. 2007, 115, 187-194. [CrossRef]

46. Phalen, R.F.; Mendez, L.B.; Oldham, M.J. New developments in aerosol dosimetry. Inhal. Toxicol. 2010, 22, 6-14. [CrossRef]

47. Abbatt, J.P.D.; Chen, W. The atmospheric chemistry of indoor environments. Environ. Sci. Process. Impacts 2020, 22, 25-48.

48. Vartiainen, E.; Kulmala, M.; Ruuskanen, T.M.; Taipale, R.; Rinne, J.; Vehkamäki, H. Formation and growth of indoor air aerosol particles as a result of d-limonene oxidation. Atmos. Environ. 2006, 40, 7882-7892. [CrossRef] 
49. Riipinen, I.; Yli-Juuti, T.; Pierce, J.R.; Petaja, T.; Worsnop, D.R.; Kulmala, M.; Donahue, N.M. The contribution of organics to atmospheric nanoparticle growth. Nat. Geosci. 2012, 5, 453-458. [CrossRef]

50. Weschler, C.J.; Shields, H.C. Indoor ozone/terpene reactions as a source of indoor particles. Atmos. Environ. 1999, 33, 2301-2312. [CrossRef]

51. Huang, H.L.; Tsai, T.J.; Hsu, N.Y.; Lee, C.C.; Wu, P.C.; Su, H.J. Effects of essential oils on the formation of formaldehyde and secondary organic aerosols in an aromatherapy environment. Build. Environ. 2012, 57, 120-125. [CrossRef]

52. Rösch, C.; Wissenbach, D.K.; von Bergen, M.; Franck, U.; Wendisch, M.; Schlink, U. The lasting effect of limonene-induced particle formation on air quality in a genuine indoor environment. Environ. Sci. Pollut. Res. 2015, 22, 14209-14219. [CrossRef]

53. Weschler, C.J. Shields Experiments Probing the Influence of Air Exchange Rates on Particles Generated by Indoor Chemistry. Indoor Air 2002, 500-505.

54. Hsu, D.-J.; Huang, H.-L.; Sheu, S.-C. Characteristics of Air Pollutants and Assessment of Potential Exposure in Spa Centers During Aromatherapy. Environ. Eng. Sci. 2012, 29, 79-85. [CrossRef]

55. Wierzbicka, A.; Bohgard, M.; Pagels, J.H.; Dahl, A.; Löndahl, J.; Hussein, T.; Swietlicki, E.; Gudmundsson, A. Quantification of differences between occupancy and total monitoring periods for better assessment of exposure to particles in indoor environments. Atmos. Environ. 2015, 106, 419-428. [CrossRef]

56. Cappellin, L.; Karl, T.; Probst, M.; Ismailova, O.; Winkler, P.M.; Soukoulis, C.; Aprea, E.; Märk, T.D.; Gasperi, F.; Biasioli, F. On quantitative determination of volatile organic compound concentrations using proton transfer reaction time-of-flight mass spectrometry. Environ. Sci. Technol. 2012, 46, 2283-2290. [CrossRef]

57. Lindinger, W.; Hansel, A.; Jordan, A. On-line monitoring of volatile organic compounds at pptv levels by means of proton-transfer-reaction mass spectrometry (PTR-MS) medical applications, food control and environmental research. Int. J. Mass Spectrom. Ion Process. 1998, 173, 191-241. [CrossRef]

58. Tani, A.; Hayward, S.; Hewitt, C.N. Measurement of monoterpenes and related compounds by proton transfer reaction-mass spectrometry (PTR-MS). Int. J. Mass Spectrom. 2003, 223-224, 561-578. [CrossRef]

59. Tani, A.; Hayward, S.; Hansel, A.; Hewitt, C.N. Effect of water vapour pressure on monoterpene measurements using proton transfer reaction-mass spectrometry (PTR-MS). Int. J. Mass Spectrom. 2004, 239, 161-169. [CrossRef]

60. Tani, A. Fragmentation and reaction rate constants of terpenoids determined by proton transfer reaction-mass spectrometry. Environ. Control Biol. 2013, 51, 23-29. [CrossRef]

61. Lee, A.; Goldstein, A.H.; Kroll, J.H.; Ng, N.L.; Varutbangkul, V.; Flagan, R.C.; Seinfeld, J.H. Gas-phase products and secondary aerosol yields from the photooxidation of 16 different terpenes. J. Geophys. Res. Atmos. 2006, 111, 1-25. [CrossRef]

62. Bianchi, F.; Kurtén, T.; Riva, M.; Mohr, C.; Rissanen, M.P.; Roldin, P.; Berndt, T.; Crounse, J.D.; Wennberg, P.O.; Mentel, T.F.; et al. Highly Oxygenated Organic Molecules (HOM) from Gas-Phase Autoxidation Involving Peroxy Radicals: A Key Contributor to Atmospheric Aerosol. Chem. Rev. 2019, 119, 3472-3509. [CrossRef]

63. Breitenlechner, M.; Fisher, L.; Hainer, M.; Heinritzi, M.; Curtius, J.; Hansel, A. PTR3: An Instrument for Studying the Lifecycle of Reactive Organic Carbon in the Atmosphere. Anal. Chem. 2017, 89, 5824-5831. [CrossRef]

64. Bernhammer, A.-K.; Fisher, L.; Mentler, B.; Heinritzi, M.; Simon, M.; Hansel, A. Production of highly oxygenated organic molecules (HOMs) from trace contaminants during isoprene oxidation. Atmos. Meas. Tech. 2018, 11, 4763-4773. [CrossRef]

65. Bonn, B.; Schuster, G.; Moortgat, G.K. Influence of water vapor on the process of new particle formation during monoterpene ozonolysis. J. Phys. Chem. A 2002, 106, 2869-2881. [CrossRef]

66. Gallimore, P.J.; Mahon, B.M.; Wragg, F.P.H.; Fuller, S.J.; Giorio, C.; Kourtchev, I.; Kalberer, M. Multiphase composition changes and reactive oxygen species formation during limonene oxidation in the new Cambridge Atmospheric Simulation Chamber (CASC). Atmos. Chem. Phys. 2017, 17, 9853-9868. [CrossRef]

67. Jonsson, Å.M.; Hallquist, M.; Ljungström, E. Impact of humidity on the ozone initiated oxidation of limonene, $\Delta 3$-carene, and $\alpha$-pinene. Environ. Sci. Technol. 2006, 40, 188-194. [CrossRef]

68. Ishizuka, Y.; Tokumura, M.; Mizukoshi, A.; Noguchi, M. Measurement of Secondary Products During Oxidation Reactions of Terpenes and Ozone Based on the PTR-MS Analysis: Effects of Coexistent Carbonyl Compounds. Int. J. Environ. Res. Public Health 2010, 7, 3853-3870. [CrossRef] 
69. Schrader, W.; Geiger, J.; Godejohann, M. Studies of complex reactions using modern hyphenated methods: A-Pinene ozonolysis as a model reaction. J. Chromatogr. A 2005, 1075, 185-196. [CrossRef]

70. Grosjean, D.; Williams, E.L.; Seinfeld, J.H. Atmospheric oxidation of selected terpenes and related carbonyls: Gas-phase carbonyl products. Environ. Sci. Technol. 1992, 26, 1526-1533. [CrossRef]

71. Jaoui, M.; Kamens, R.M. Gaseous and particulate oxidation products analysis of a mixture of a-pinene + b-pinene/O3/air in the absence of light and a-pinene $+\mathrm{b}$-pinene/NOx/air in the presence of natural sunlight. Sect. Title Air Pollut. Ind. Hyg. 2003, 44, 259-297.

72. Librando, V.; Tringali, G. Atmospheric fate of $\mathrm{OH}$ initiated oxidation of terpenes. Reaction mechanism of $\alpha$-pinene degradation and secondary organic aerosol formation. J. Environ. Manag. 2005, 75, 275-282. [CrossRef]

73. Larsen, B.O.R.; Bella, D.D.I.; Glasius, M.; Winterhalter, R.; Jensen, N.R.; Hjorth, J. Gas-Phase OH Oxidation of Monoterpenes: Gaseous and Particulate Products. J. Atmos. Chem. 2001, 38, 231-276. [CrossRef]

74. Schroeder, L.M.; Weslien, J. Reduced offspring production in bark beetleTomicus piniperda in pine bolts baited with ethanol and $\alpha$-pinene, which attract antagonistic insects. J. Chem. Ecol. 1994, 20, 1429-1444. [CrossRef]

75. Rodríguez, A.; Andrés, V.S.; Cervera, M.; Redondo, A.; Alquézar, B.; Shimada, T.; Gadea, J.; Rodrigo, M.; Zacarías, L.; Palou, L.; et al. The monoterpene limonene in orange peels attracts pests and microorganisms. Plant Signal. Behav. 2011, 6, 1820-1823. [CrossRef]

76. Bäck, J.; Aalto, J.; Henriksson, M.; Hakola, H.; He, Q.; Boy, M. Chemodiversity of a Scots pine stand and implications for terpene air concentrations. Biogeosciences 2012, 9, 689-702. [CrossRef]

77. Tarvainen, V.; Hakola, H.; Hellén, H.; Bäck, J.; Hari, P.; Kulmala, M. Temperature and light dependence of the VOC emissions of Scots pine. Atmos. Chem. Phys. 2005, 5, 989-998. [CrossRef]

78. Janson, R.W. Monoterpene emissions from Scots pine and Norwegian spruce. J. Geophys. Res. Atmos. 1993, 98, 2839-2850. [CrossRef]

79. Hiltunen, R.; Laakso, I. Gas chromatographic analysis and biogenetic relationships of monoterpene enantiomers in Scots Pine and juniper needle oils. Flavour Fragr. J. 1995, 10, 203-210. [CrossRef]

80. Haypek, E.; Silva, L.H.; Batista, E.; Marques, D.S.; Meireles, M.A.A.; Meirelles, A.J.A. Recovery of aroma compounds from orange essential oil. Braz. J. Chem. Eng. 2000, 17, 705-712. [CrossRef]

81. Sarwar, G.; Corsi, R. The effects of ozone/limonene reactions on indoor secondary organic aerosols. Atmos. Environ. 2007, 41, 959-973. [CrossRef]

82. Hansela, A.; Jordana, A.; Holzingera, R.; Prazellera, P.; Vogelb, W.; Lindingera, W. Proton transfer reaction mass spectrometry: On-line trace gas analysis at the ppb level. Int. J. Mass Spectrom. Ion Process. 1995, 149, 609-619. [CrossRef]

83. Jordan, A.; Haidacher, S.; Hanel, G.; Hartungen, E.; Märk, L.; Seehauser, H.; Schottkowsky, R.; Sulzer, P.; Märk, T.D. A high resolution and high sensitivity proton-transfer-reaction time-of-flight mass spectrometer (PTR-TOF-MS). Int. J. Mass Spectrom. 2009, 286, 122-128. [CrossRef]

84. SIS Tenax®TA Breakthrough Volume Data. Available online: https:/www.sisweb.com/index/referenc/ tenaxta.htm (accessed on 2 February 2020).

85. Marć, M.; Namieśnik, J.; Zabiegała, B. Small-scale passive emission chamber for screening studies on monoterpene emission flux from the surface of wood-based indoor elements. Sci. Total Environ. 2014, 481, 35-46. [CrossRef]

86. Salthammer, T. Formaldehyde sources, formaldehyde concentrations and air exchange rates in European housings. Build. Environ. 2019, 150, 219-232. [CrossRef] 
87. Rovira, J.; Roig, N.; Nadal, M.; Schuhmacher, M.; Domingo, J.L. Human health risks of formaldehyde indoor levels: An issue of concern. J. Environ. Sci. Health Part A Toxic/Hazard. Subst. Environ. Eng. 2016, 51, 357-363. [CrossRef] [PubMed]

88. Salthammer, T.; Schulz, N.; Stolte, R.; Uhde, E. Human sensory response to acetone/air mixtures. Indoor Air 2016, 26, 796-805. [CrossRef]

Sample Availability: Samples of the compounds studied in this research are available from the authors.

(C) 2020 by the authors. Licensee MDPI, Basel, Switzerland. This article is an open access article distributed under the terms and conditions of the Creative Commons Attribution (CC BY) license (http://creativecommons.org/licenses/by/4.0/). 